\title{
Relevance of the Fusarium toxins deoxynivalenol and zearalenone in ruminant nutrition. A review
}

\author{
K. Seeling ${ }^{1}$ and S. Dänicke \\ Institute of Animal Nutrition, Federal Agricultural Research Centre (FAL), Braunschweig \\ Bundesallee 50, D-38116 Braunschweig, Germany
}

(Received 28 July 2004; revised version 12 November 2004; accepted 31 January 2005)

\begin{abstract}
Deoxynivalenol (DON) and zearalenone (ZON) produced by Fusarium species are agriculturally important mycotoxins of relevance to livestock health. While ZON is known to cause oestrogenic syndromes in animals, a moderate ingestion of DON is associated with reduced performance and immune function. Among farm animals, ruminants appear to have a higher tolerance towards the effects of DON and ZON. As a consequence, feed producers may allocate cereals and roughages which appear contaminated with Fusarium toxins to ruminants. In combination with enhanced toxin concentrations during so-called Fusarium years, the possible effects in ruminants cannot be overlooked. However, only limited and inconsistent literature data are available about the effects of DON and ZON on ruminants. On the basis of the literature, the kinetics, biotransformation and carry over, as well as the effects of DON and ZON on ruminants, are reviewed. Furthermore, dosage and duration of toxin exposure as well as genetic and physiological factors of ruminants which could influence the variability of the toxin effects are considered and discussed. It is concluded that additional research is needed to study the effects of DON and ZON on ruminants, especially in lactating dairy cows.
\end{abstract}

KEY WORDS: deoxynivalenol, zearalenone, ruminants

\section{INTRODUCTION}

Mycotoxins are a diverse group of toxic secondary metabolites produced by a wide range of filamentous fungi. It is assumed that more than 300 chemically different mycotoxins exist, formed by more than 350 fungal species (Steyn, 1998). With regard to the occurrence of mycotoxins in feedstuffs, three genera of fungi may be considered to be of particular importance: Aspergillus, Penicillium and Fusarium (Bauer, 2000). Among these the moulds of the genus Fusarium are the most important under agricultural conditions in Central Europe (Lew, 1995).




Fusaria are traditionally considered so-called field flora, because these plant pathogens can infect grains at the flowering period and accumulate toxins during the vegetation stage (Bottalico, 1998). The most important Fusarium toxins from the point of view of animal health and productivity are DON and ZON (D'Mello et al., 1999). These toxins are most commonly found in Europe, predominantly produced by Fusarium culmorum and Fusarium graminearum (Bottalico and Perrone, 2002). Especially in years with unfavourable climatic conditions (periods of warm weather with persistent wetness; Sutton, 1982; Oldenburg et al., 2000), the contamination of cereal grains and maize plants with Fusarium species can cause considerable agricultural problems resulting in yield loss, quality loss and mycotoxin contamination. With regard to a preventive consumer protection, the carry over of the mycotoxins in animal-derived food products has to be considered.

Numerous investigations on the natural occurrence of Fusarium toxins in cereals and forage crops have been carried out during the past years (Tables 1 and 2). It is conspicuous that crop years with higher maximum and mean DON as well as ZON concentrations occur repeatedly (Oldenburg et al., 2000). Due to the high proportion of cereals, as well as forage crops such as maize and grass silage, hay and straw in ruminant diets, both concentrate feeds and basic rations can contribute to the daily toxin exposure of ruminants (Scudamore and Livesey, 1998). Furthermore, since ruminants are regarded as relatively resistant to DON and ZON compared with monogastric animals such as pigs, feed manufacturers will feed cereals which appear contaminated with Fusarium toxins primarily to ruminants rather than to pigs. In combination with higher DON and ZON concentrations in cereals and roughages during so called Fusarium years, possible mycotoxin effects in ruminants should not be underestimated (Oldenburg et al., 2000; Dänicke et al., 2002a).

Generally, the higher tolerance of ruminants to DON and ZON is attributed to the potential of rumen microbes for metabolization of these toxins. However, up to now these effects were only proved in some in vitro investigations with incubated rumen fluid. Only a limited number of corresponding in vivo studies, especially with lactating dairy cows, are available and were mainly focussed on pharmacokinetic aspects. Further literature data about the effects of DON and ZON contaminated feedstuffs on the health and performance of ruminants and on nutrient digestibility are relatively rare. Because mostly only case or field reports as well as studies with a limited number of animals and rather short experimental periods were given (for reviews see Hölthershinken et al., 1996; Whitlow and Hagler, 1999; Bauer, 2000; Dänicke et al., 2000) the described effects of DON and $\mathrm{ZON}$ on ruminants are not always consistent between the different studies.

The purpose of this article is to summarize the actual state of knowledge regarding the kinetics, biotransformation and carry over of the Fusarium toxins DON and ZON in ruminants considering their mode of action. Furthermore, the effects of DON and ZON in dependence of toxin exposure on ruminant health 


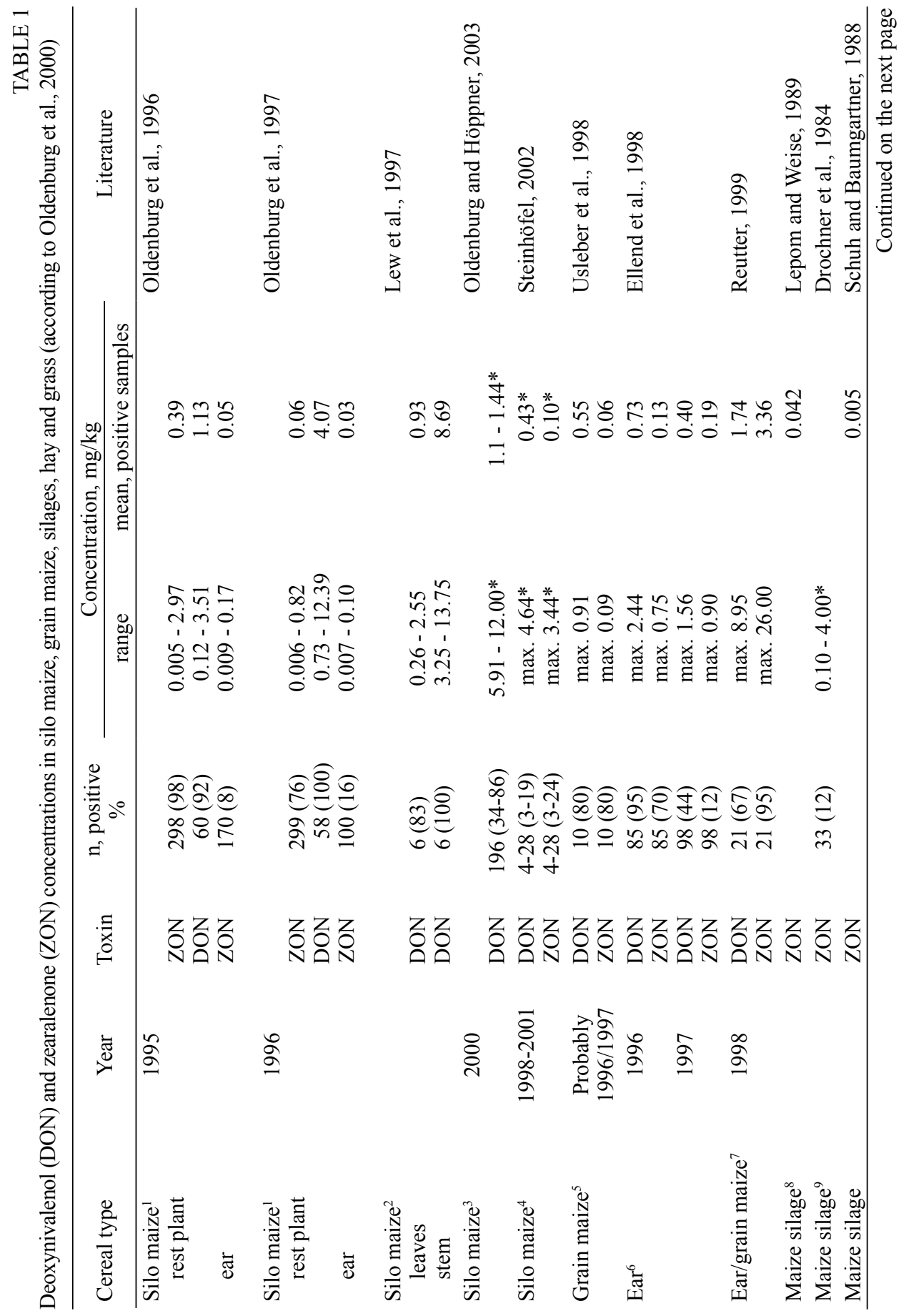







爵

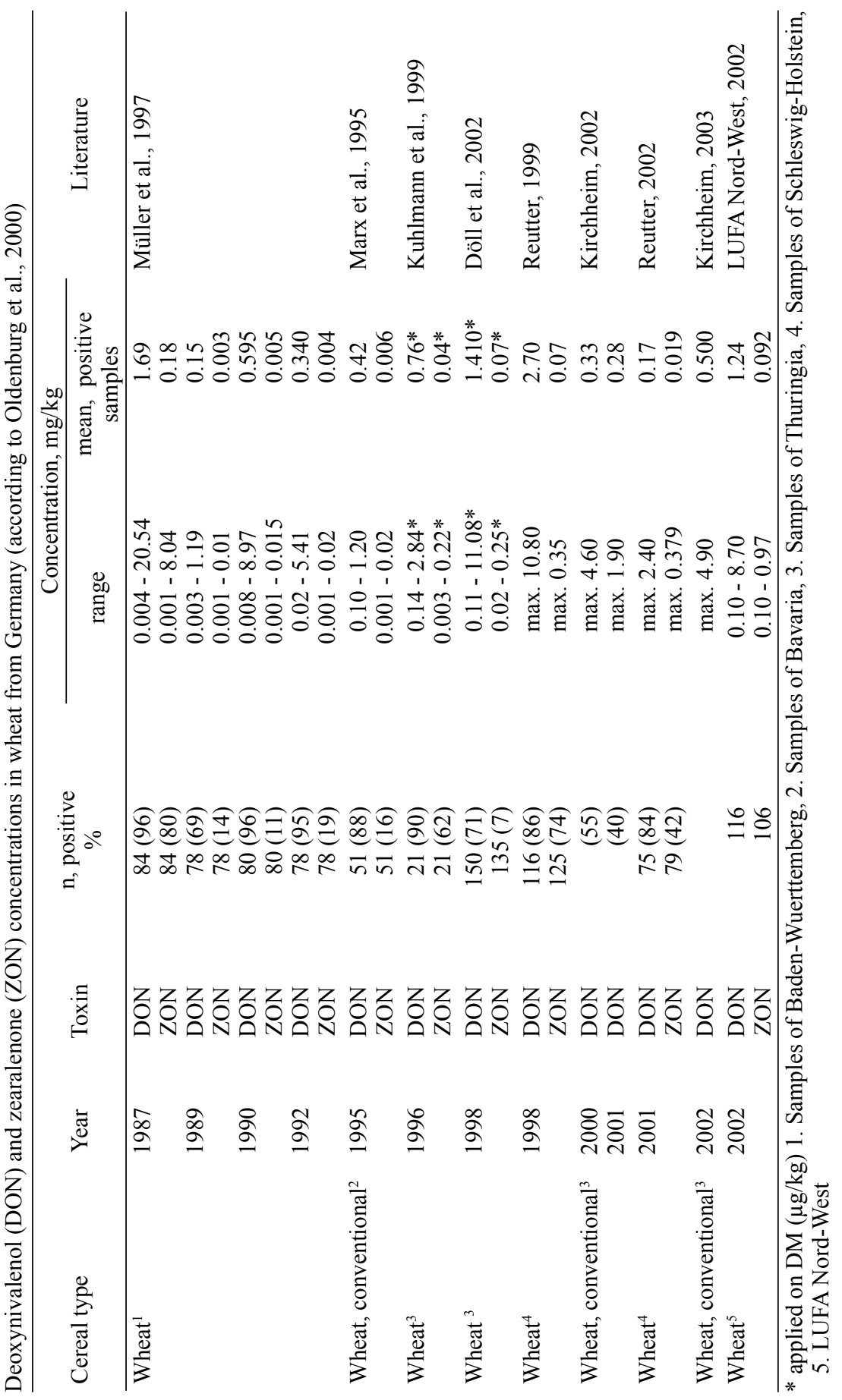


and performance, as well as factors which could influence the variability of toxin effects and the carry over are discussed.

\section{MODE OF ACTION}

\section{Trichothecenes including deoxynivalenol}

DON (3 $\alpha, 7 \alpha, 15$-trihydroxy-12, 13-epoxytrichothec-9-ene-8-one) belongs chemically to the trichothecenes, which comprise a family of 170 closely related sesquiterpenoids (Langseth et al., 2001; Figure 1). Trichothecenes possess a basic and tetracyclic structure which includes a six member oxygen-containing ring, an epoxide in the C-12, 13 position and an olefinic bond in the C-9, 10 position (Betina, 1989). Wide differences in biological activity exist among the several trichothecenes, which is determined by the chemical structure (Betina, 1989).
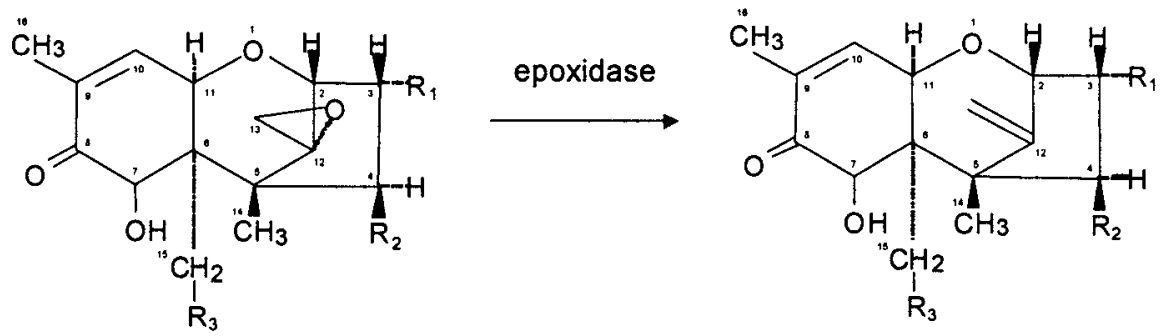

Figure 1. Deepoxidation of trichothecenes to de-epoxy trichothecenes (King et al., 1984)

According to the structural features, trichothecenes can be divided into types A, B, C and D (Ueno, 1985; Rotter et al., 1996). Type A is characterized by a lack of the functional ketone group at C-8 and includes T-2 toxin (T2), T2-tetraol, T2-triol, HT-2 toxin (HT2), diacetoxyscirpenol (DAS), neosolaniol (NEO), monoacetoxyscirpenol (MAS), scirpentriol (Bottalico, 1998). Type B has a carbonyl group at C-8 and is represented by DON, nivalenol (NIV), fusarenon-X (FUS-X), 15-acetyldeoxynivalenol (15-AcDON) and 3-acetyldeoxynivalenol (3-AcDON). Type $\mathrm{C}$ is characterized by a second epoxy group at C-7, 8 or C-9, 10 and includes crotocin, and type $\mathrm{D}$ is characterized by a macrocyclic ring between C-4 and C-15 and includes derivates of verrucarins and verrucarol.

The basic mechanism of trichothecenes is the inhibition of the protein synthesis at the ribosomal level (Feinberg and McLaughlin, 1989). They bind to the 60S subunit of eukaryotic ribosomes and inhibit the peptidyl transferase activity. Type B trichothecenes including DON are capable of blocking translation at the elongation stage. Moreover, number and positions of substituents at the molecule modify the inhibitory properties (Betina, 1989). The presence of an intact C-9, 10 double bond 
and the C-12, 13 epoxide is required for the inhibitory effect, while reduction of the epoxide ring (deepoxidation) results in loss of any apparent toxicity (McLaughlin et al., 1977; Ehrlich and Diagle, 1987; Figure 1). Such a detoxification occurs for DON that is de-epoxidised to the non-toxic metabolite de-epoxy DON as shown for rumen microbes (King et al., 1984).

\section{Zearalenone}

ZON is chemically described as 6-(10-hydroxy-6-oxo-trans-1-undecenyl)$\beta$-resorcyclic acid lactone with the molecular formula $\mathrm{C}_{18} \mathrm{H}_{22} \mathrm{O}_{5}$ (Figure 2). It was given the trivial name zearalenone as a combination of the fragments coming from Gibberella zeae, resorcyclic acid lactone, -ene (for the presence of the C-1 ${ }^{1}$ to $\mathrm{C}-2$ double bond) and - one, for the C-6 ketone (Urry et al., 1966).

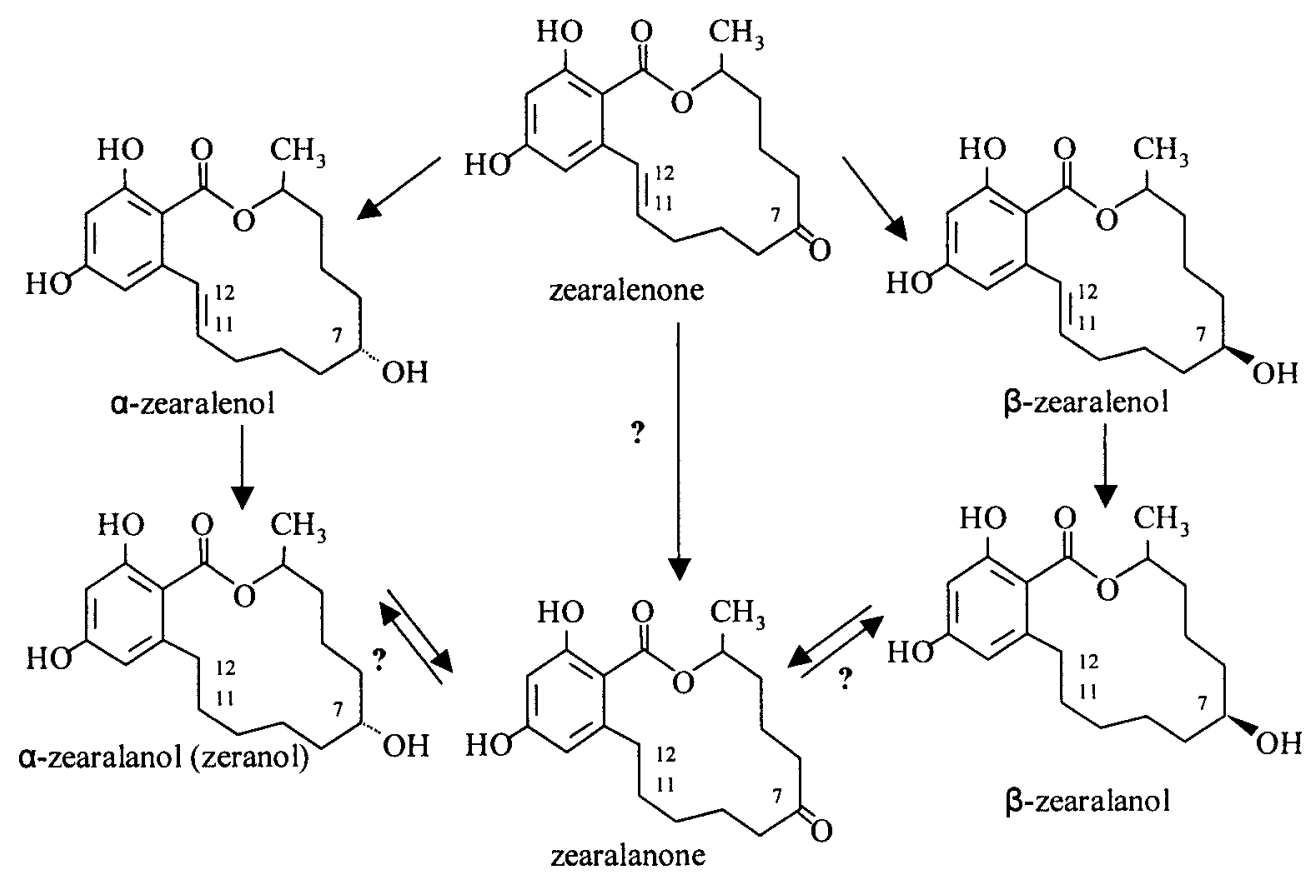

Figure 2. Proposed relationship between routes of zearalenone and its metabolites (Kleinova et al., 2002)

ZON is a non-steroidal mycotoxin, which possesses - beside the anabolic mode of action - primarily oestrogenic properties (Kuiper-Goodman et al., 1987; Figure $2)$. The reduced products $\alpha$-zearalenol $(\alpha-Z O L)$ and $\beta$-zearalenol $(\beta-Z O L)$ are the primary metabolites of ZON (IARC, 1993), further derivates are zearalanone (ZAN), zeranol ( $\alpha$-ZAL) and taleranol ( $\beta$-ZAL; Figure 2). 
ZON and its derivates induce oestrogenic effects which are mediated via a competitive binding to the cytosolic oestrogen receptor. The receptor-toxincomplex is rapidly transferred into the nucleus, where it binds to specific nuclear receptors and generates oestrogenic responses via gene activation, resulting in the production of mRNAs that code for proteins that are normally expressed by receptor-oestrogen complex binding (Riley, 1998). Values for oestrogen receptor binding in target tissues and cells relative to oestradiol of ZON range between $<0.01-0.1$, whereas the relative binding affinities to rat uterine cytoplasmatic receptor for ZON and derivates were $\alpha-\mathrm{ZAL}>\alpha-\mathrm{ZOL}>\beta-\mathrm{ZAL}>\mathrm{ZON}>\beta-\mathrm{ZOL}$ (Tashiro et al., 1980; Kuiper-Goodman et al., 1987; Eriksen and Alexander, 1998). Furthermore, Fitzpatrick et al. (1989) showed that considerable differences in the affinity of $\alpha$-ZOL to the oestrogen receptor exist between different animal species. Moreover, the relative oestrogenic potencies appear to closely parallel to the relative binding affinity of ZON and its derivates for the uterine cytoplasmic receptor in rodents (Pathre and Mirocha, 1976). Ueno and Tashiro (1981) reported the order of potencies to be $\alpha$-ZAL $>\alpha-Z O L>\beta-Z A L>Z O N>\beta-Z O L$. Thus, $\alpha-Z O L$ is about $3-4$ times more oestrogenic than $\mathrm{ZON}$, however $\beta$-ZOL is generally less active (Hagler et al., 1980). Consequently, the reduction of $Z O N$ to $\alpha-Z O L$ involves an activation of the toxin, while the reduction to $\beta-Z O L$ possibly means the contrary (Olsen et al., 1989).

\section{KINETICS, BIOTRANSFORMATION AND CARRY OVER}

\section{Deoxynivalenol}

Literature data concerning the kinetic behaviour of DON in ruminants are relative rare (Table 3). Prelusky et al. (1984) administered a single oral dose of DON at levels of $1.7 \mathrm{mg} / \mathrm{kg}$ body weight (BW) to dairy cows and reported an absorption of approximately $0.6 \%$ of the parent toxin. Maximum serum levels of free and conjugated DON for two dosed cows were 200 and $90 \mathrm{ng} / \mathrm{ml}$ occurring at 4.7 and $3.5 \mathrm{~h}$ after dosing. Only traces $(<2 \mathrm{ng} / \mathrm{ml})$ were detectable $24 \mathrm{~h}$ after DON administration. $24-46 \%$ of the total DON level in serum occurred as the B-glucuronide conjugate. Lower oral DON doses of $0.1 \mathrm{mg} / \mathrm{kg}$ BW were not detectable in serum. In a study by Cote et al. (1986) dairy cows were fed a DON spiked diet (average $66 \mathrm{mg} / \mathrm{kg}$ diet) for five days. $20 \%$ of DON fed was recovered in similar proportions as the unconjugated metabolites in the urine $(11 \%)$ and faeces $(9 \%)$, whereby the ratio of DON and de-epoxy DON was 1 to 24 . After incubation of urine with $\beta$-glucuronidase, concentration of DON and de-epoxy DON increased 1.6 to 3 -fold and 7 to 15 -fold, respectively, which indicates that the most DON consumed was eliminated in the urine as de-epoxy DON conjugate. 
㩊

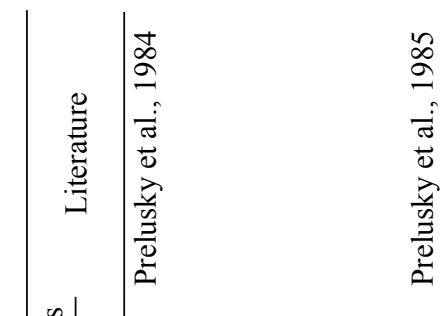





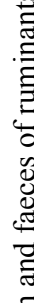

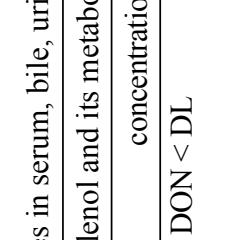

E

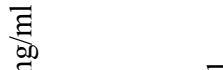

$\bar{g} \cdot \frac{20}{0}$

흘

요

क्रि $\bar{\Xi}$

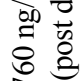

ํํㅇㅇㅛ

ह

च कि

芒离

ठें छิ

तิ

离

:

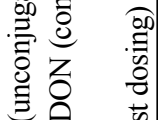

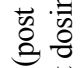

ज㻤

艺究

†

훌

文

궁

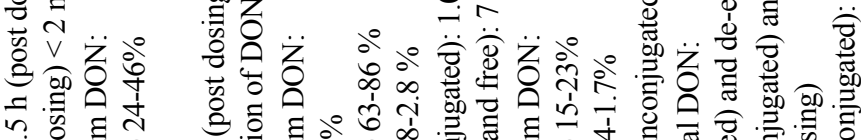

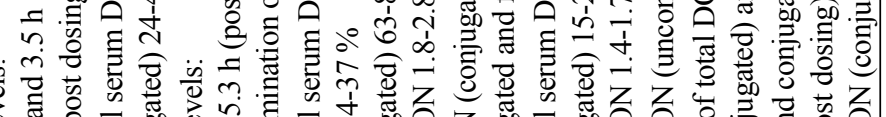





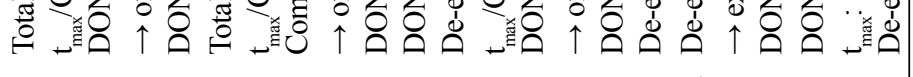

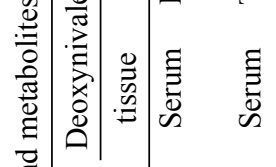

惡

氙

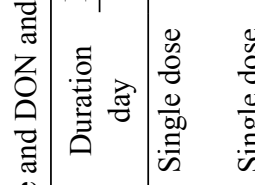

0
0
0
0
00
0
0

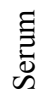



文

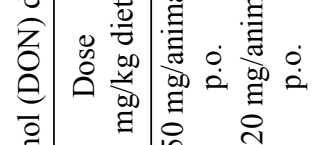

产

in \&

0
0
0
00
0
0

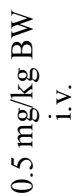

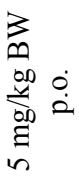

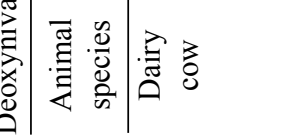

$\frac{8}{\mathscr{D}}$

言言 喜 







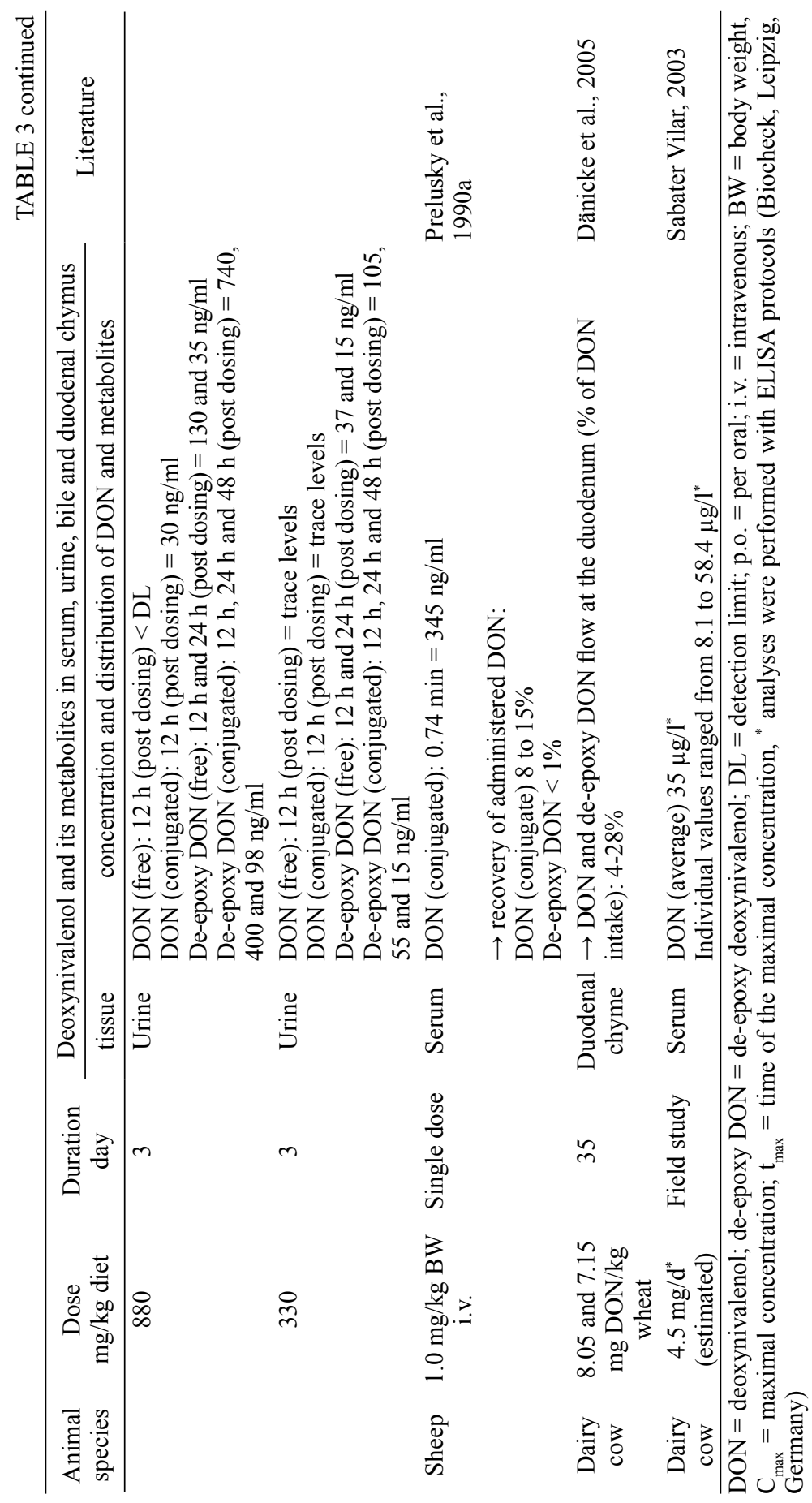


Also, the pharmacokinetics of DON in sheep were investigated. Following a single oral administration of $5 \mathrm{mg} / \mathrm{kg}$ BW only a small percentage of $6-10 \%$ of the dose was absorbed into the circulatory system as the parent toxin (Prelusky et al., 1985). Conjugated DON of the total plasma DON accounted for $63-86 \%$, with a small fraction present as conjugated de-epoxy DON (1.8-2.8\%). Following single intravenous DON administrations of $0.5 \mathrm{mg} / \mathrm{kg} \mathrm{BW}$ and $1 \mathrm{mg} / \mathrm{kg} \mathrm{BW}$ only $15-23 \%$ and $8-15 \%$ of total plasma DON occurred as the DON conjugate, 1.4 to $1.7 \%$ and $<1 \%$ as the de-epoxy DON conjugate, respectively (Prelusky et al., 1985, 1990a). These results suggested that the toxin will go directly to the liver where it can possibly undergo extensive conjugation as a "first-pass effect" when absorbed from the gastrointestinal tract. Glucuronic acid conjugation appears to be an important metabolic pathway, while in comparison, deepoxidation appears to be only a very minor pathway of systemic DON metabolism. Moreover, in subsequent studies DON was administrated intravenous $(0.5 \mathrm{mg} / \mathrm{kg}$ and $4 \mathrm{mg} / \mathrm{kg}$ BW) and was rapidly cleared from the body, essentially excreted in the urine mostly in the form of the glucuronide conjugates (Prelusky et al., 1986, 1987). This suggests that metabolic conjugation of DON appeared to be an important step in its elimination. Furthermore, comparison of systemic elimination of DON and metabolites through urinary and biliary routes suggests that biliary excretion does not play an important role, while urinary excretion appeared to be the most important mechanism (Prelusky et al., 1986).

It is of interest to note that following a large single oral or an intravenous dose of DON, only very little de-epoxy DON (free or conjugated) could be measured in the blood, however a more prolonged oral exposure with a DON contaminated diet for three days resulted in conjugated de-epoxy DON being the major component detected (Prelusky et al., 1987). This appears to be a result of the extended exposure of DON to the rumen microflora, which have the capacity to convert DON to de-epoxy DON. These findings are supported by Dänicke et al. (2004) who fed fistulated dairy cows with Fusarium toxin contaminated wheat ( 8.05 and $7.15 \mathrm{mg} \mathrm{DON} / \mathrm{kg}$ wheat) over a $35 \mathrm{~d}$ period. Only a small fraction of ingested DON of $15 \%$ was recovered at the duodenum and the majority (89\%) was in the form of de-epoxy DON. Also, the authors suggested a complete degradation of the molecule in the rumen or an absorption by the mucosa of the rumen. Moreover, Prelusky et al. (1985) estimated the systemic bioavailability of DON in sheep at $7.5 \%$ on average due in part to its rapid and efficient metabolism by rumen microorganisms. In contrast, adverse results have been obtained by Sabater Vilar (2003). A mean DON content of $32 \mu \mathrm{g} / \mathrm{L}$ was detected in blood serum of dairy cows belonging to a Dutch farm. Based on an average daily intake of $20 \mathrm{~kg}$ dry matter, the estimated individual daily DON exposure was $4.5 \mathrm{mg}$. Sabater Vilar (2003) concluded that these 
results clearly indicate a disability of the rumen to degrade the amount of DON to which the animals were exposed. Taking into account that blood samples were analysed by using a DON ELISA these results should be interpreted carefully. Additional investigations on ruminants, especially long term studies with defined experimental conditions, should be performed to evaluate the biotransformation of DON which is essential to evaluate possible carry over into milk.

Carry over of DON and de-epoxy DON to animal products of ruminants is only investigated for transmission in the milk, however no information is available on residues in edible tissues (Table 4). Following a single oral dose of $1.7 \mathrm{mg} / \mathrm{kg}$ BW to lactating cows, concentrations of free and conjugated DON in

TABLE 4

Deoxynivalenol (DON) dose and DON and metabolites in milk of ruminants (following Dänicke et al., 2000)

\begin{tabular}{|c|c|c|c|c|}
\hline $\begin{array}{l}\text { Animal } \\
\text { species }\end{array}$ & $\begin{array}{c}\text { Dose } \\
\mathrm{mg} / \mathrm{kg} \text { diet }\end{array}$ & $\begin{array}{l}\text { Duration } \\
\text { Day }\end{array}$ & Toxins and metabolites in milk, $\mu \mathrm{g} / \mathrm{l}$ & Literature \\
\hline $\begin{array}{l}\text { Dairy } \\
\text { cow }\end{array}$ & 920 mg p.o. & $\begin{array}{l}\text { Single } \\
\text { dose }\end{array}$ & $\begin{array}{l}\text { Traces of DON }(<4) \text { (with and without } \\
\text { incubation with glucuronidase) }\end{array}$ & Prelusky et al., 1984 \\
\hline $\begin{array}{l}\text { Dairy } \\
\text { cow }\end{array}$ & $50 \mathrm{mg}$ p.o. & $\begin{array}{c}\text { Single } \\
\text { dose }\end{array}$ & $<10$ & \\
\hline $\begin{array}{l}\text { Dairy } \\
\text { cow }\end{array}$ & 66 & 5 & DON $<$ DL, de-epoxide-DON: 2-26 & Cote et al., 1986 \\
\hline Sheep & $\begin{array}{l}880 \\
330\end{array}$ & $\begin{array}{l}3 \\
3\end{array}$ & $\begin{array}{l}\mathrm{C}_{\max }: \mathrm{DON}=17, \text { de-epoxy-DON }=205 \\
\mathrm{C}_{\max }: \mathrm{DON}=10, \text { de-epoxy-DON }=125\end{array}$ & Prelusky et al., 1987 \\
\hline $\begin{array}{l}\text { Dairy } \\
\text { cow }\end{array}$ & $\begin{array}{l}0,6,12 \mathrm{mg} / \mathrm{kg} \\
\text { concentrate } \\
\text { feed }\end{array}$ & 70 & DON and de-epoxy DON $<1$ & Charmley et al., 1993 \\
\hline
\end{tabular}

$\mathrm{DON}=$ deoxynivalenol; de-epoxy $\mathrm{DON}=$ de-epoxy deoxynivalenol; $\mathrm{DL}=$ detection limit; p.o. $=$ per oral; $\mathrm{C}_{\max }=$ maximal concentration

the milk were $1-3 \mathrm{ng} / \mathrm{ml}$ at $8 \mathrm{~h}$, and $<1-2 \mathrm{ng} / \mathrm{ml}$ at $20 \mathrm{~h}$ after dosing, respectively (Prelusky et al., 1984). Furthermore, extremely high oral doses of 4.0 and $1.5 \mathrm{~g}$ pure DON administered over a $72 \mathrm{~h}$ period to sheep resulted in maximum total DON residues of 222 and $135 \mathrm{ng} / \mathrm{ml}$, respectively (Prelusky et al., 1987). Only trace amounts of DON, essentially as conjugated de-epoxy DON could be detected 44-48 $\mathrm{h}$ after the last exposure to DON. Cote et al. (1986) detected no unconjugated DON, however concentrations of unconjugated de-epoxy DON ranged up to $26 \mathrm{ng} / \mathrm{ml}$. The authors stress the difference between multiple and single dose administration, but in a study of Charmley et al. (1993) no DON and de-epoxy DON residues were measured in milk from cows when consumed up to $100 \mathrm{mg} / \mathrm{d}$ for 70 days. 


\section{Zearalenone}

Kiessling and Petterson (1978) reported on two principal pathways of ZON metabolism in liver homogenate or isolated microsomes of rats using an in vitro study: conjugation with glucuronic acid (enzyme glucuronosyltransferase) and reduction to $\alpha$ - or $\beta$-ZOL (enzyme $3 \alpha$ ( $\beta$ )-hydroxysteroid dehydrogenase). Investigations on the subcellular distribution of the $\mathrm{ZON}$ reducing activity in the liver of cows showed that the NADH- and NADPH-dependent $\alpha-Z O L$ formation were located almost entirely in the microsomal fraction, while $\beta$-ZOL formation occurred only in the cytosol fraction with NADPH as coenzyme and no detectable amounts were formed with NADH as coenzyme (Olsen and Kiessling, 1983).

Relatively little information is available about the kinetic behaviour of ZON in ruminants (Table 5). Prelusky et al. (1990b) detected only trace amounts of conjugated ZON declining rapidly to negligible levels following an oral exposure to cows with a ZON contaminated diet $(544.5 \mathrm{mg} / \mathrm{d})$ over a period of 21 days or after oral one-day ZON doses of 1.8 and $6.0 \mathrm{~g}$. In another study, Mirocha et al. (1981) found urinary and faecal excretions of free and conjugated (glucuronic and sulphate) ZON of 29 and $25 \%, \alpha$-ZOL of 20 and $12 \%$ as well as $\beta-Z O L$ of 51 and $58 \%$ of ZON ingested by cows, whereby the ZON-, $\alpha-Z O L-$ and $\beta$-ZOL-glucuronide conjugates of the total urinary ZON accounted for 73.7, 52.9 and $70.0 \%$. These results indicate that the predominant metabolite in urine and faeces was $\beta-Z O L$, mainly appearing as glucuronide conjugate. These findings agree with those of Kleinova et al. (2002) who concluded from investigations on heifers which were fed with ZON contaminated oats $(1.4 \mathrm{mg} / \mathrm{kg})$ for 84 days that $80 \%$ of the ingested $\mathrm{ZON}$ analysed as the sum of the parent compound and its metabolites were excreted in urine as $\alpha-Z O L$ and $\beta$-ZOL in the ratio 1:8. The concentrations of ZON, $\alpha-Z O L$ and $\beta$-ZOL in the liver were distinctly lower than those observed in the urine, the ratio of $\alpha-Z O L$ and $\beta$-ZOL was 1:5. Dänicke et al. (2002a) reported on $\beta$-ZOL concentrations of $68 \%$ of total detected metabolites in bile whereas the respective percentages of $\alpha-Z O L$ and ZON were 8 and $24 \%$ due to feeding Fusarium contaminated wheat $(0.1 \mathrm{mg} Z \mathrm{ZON} / \mathrm{kg}$ complete ration) to growing bulls. Similarly, Kennedy et al. (1998) found the ratio between $\alpha-Z O L$ and $\beta$-ZOL in the range from 1:2 and 1:3 in bile samples of cattle exposed with naturally ZON contaminated feedstuffs.

With regard to the ban of all hormonal substances used for the purposes of growth promotion of domestic livestock by the European Union in 1988 (Council Directive $88 / 146$ ), it is important to note that the metabolite $\alpha$-ZAL, which was used as a growth promoter in beef cattle fattening in the past by commercial preparation of zearalenone marketed under the name Ralgro (International Minerals and Chemical 
TABLE 5

Zearalenone (ZON) dose and ZON and metabolites in serum, bile, urine, duodenal chyme and faeces of ruminants

\begin{tabular}{|c|c|c|c|c|c|}
\hline \multirow{2}{*}{$\begin{array}{l}\text { Animal } \\
\text { species }\end{array}$} & \multirow{2}{*}{$\begin{array}{c}\text { Dose } \\
\mathrm{mg} / \mathrm{kg} \text { diet }\end{array}$} & \multirow{2}{*}{$\begin{array}{c}\text { Duration } \\
\text { day }\end{array}$} & \multicolumn{2}{|c|}{$\begin{array}{l}\text { Zearalenone and metabolites in serum, urine, bile, } \\
\text { duodenal chyme and faeces }\end{array}$} & \multirow{2}{*}{ Literature } \\
\hline & & & tissue & $\begin{array}{c}\text { concentration and/or distribution of DON and } \\
\text { metabolites }\end{array}$ & \\
\hline \multirow[t]{2}{*}{$\begin{array}{c}\text { Dairy } \\
\text { cow }\end{array}$} & 100 & 7 & Urine & $\begin{array}{l}\rightarrow \text { Distribution of ZON (conjugated and free): } \\
\text { ZON } 29 \%, \alpha-Z \text { ZOL } 20 \%, \beta-Z \text { ZOL } 51 \%\end{array}$ & \multirow[t]{2}{*}{$\begin{array}{l}\text { Mirocha } \\
\text { et al., } 1981\end{array}$} \\
\hline & & & Faeces & $\begin{array}{l}\rightarrow \text { Distribution of ZON (conjugated and free): } \\
\text { ZON } 25 \%, \alpha-Z O L ~ 12 \%, \beta-Z O L 58 \%\end{array}$ & \\
\hline \multirow[t]{2}{*}{ Ewe } & $\begin{array}{l}1 \mathrm{mg} \text { deuterio- } \\
\text { ZON i.v. }\end{array}$ & $\begin{array}{l}\text { Single } \\
\text { dose }\end{array}$ & Urine & $\begin{array}{l}\text { ZON, } \alpha-Z O L, \beta-Z O L, \alpha-Z A L \text { and } \beta-Z A L \\
\text { detectable }\end{array}$ & \multirow[t]{2}{*}{$\begin{array}{l}\text { Miles } \\
\text { et al., } 1996\end{array}$} \\
\hline & $\begin{array}{l}\text { 5mg deuterio- } \\
\text { ZON p.o. }\end{array}$ & $\begin{array}{l}\text { Single } \\
\text { dose }\end{array}$ & Urine & $\begin{array}{l}\mathrm{ZON}, \alpha-\mathrm{ZOL}, \beta-\mathrm{ZOL}, \alpha-\mathrm{ZAL} \text { and } \beta-\mathrm{ZAL} \\
\text { detectable }\end{array}$ & \\
\hline \multirow[t]{4}{*}{ Cattle } & $10 \mathrm{mg} Z \mathrm{ZON}$ & $\begin{array}{l}\text { Single } \\
\text { dose }\end{array}$ & Bile & $\begin{array}{l}\mathrm{t}_{\max } / \mathrm{C}_{\max }: Z A L: 96 \mathrm{~h} \text { (post dosing) }=3 \mathrm{ng} / \mathrm{ml} \\
\mathrm{t}_{\max } / \mathrm{C}_{\max }: \alpha-Z \mathrm{ZOL}: 24 \mathrm{~h} \text { (post dosing) }=150 \mathrm{ng} / \mathrm{ml}\end{array}$ & \multirow[t]{4}{*}{$\begin{array}{l}\text { Kennedy } \\
\text { et al., } 1998\end{array}$} \\
\hline & $10 \mathrm{mg} \alpha-\mathrm{ZOL}$ & $\begin{array}{l}\text { Single } \\
\text { dose }\end{array}$ & Bile & $\begin{array}{l}\mathrm{t}_{\max } / \mathrm{C}_{\max }: Z A L: 240 \mathrm{~h} \text { (post dosing) }=20 \mathrm{ng} / \mathrm{ml} \\
{ }_{\max } / C_{\max }: \alpha-Z O L: 12-24 \mathrm{~h} \text { (post dosing) }=200 \mathrm{ng} / \mathrm{ml}\end{array}$ & \\
\hline & $10 \mathrm{mg} \beta-\mathrm{ZOL}$ & $\begin{array}{l}\text { Single } \\
\text { dose }\end{array}$ & Bile & $\begin{array}{l}\text { ZAL: not detectable } \\
\mathrm{t}_{\max } / \mathrm{C}_{\max }: \alpha-Z O L: 24 \mathrm{~h} \text { (post dosing) }=60 \mathrm{ng} / \mathrm{ml}\end{array}$ & \\
\hline & $\begin{array}{l}\mathrm{ZON}+\alpha-\mathrm{ZOL} \\
\quad+\beta-\mathrm{ZOL}\end{array}$ & $\begin{array}{l}\text { Single } \\
\text { dose }\end{array}$ & Bile & $\mathrm{A}-\mathrm{ZOL}>\mathrm{ZON}>\beta-\mathrm{ZOL}$ & \\
\hline \multirow[t]{3}{*}{$\begin{array}{l}\text { Dairy } \\
\text { cow }\end{array}$} & $544.5 \mathrm{mg} \mathrm{ZON}$ & 21 & Serum & $\mathrm{t}_{\max } / \mathrm{C}_{\max }: \mathrm{ZON}$ (conjugated): $62 \mathrm{~h}=3 \mathrm{ng} / \mathrm{ml}$ & \multirow[t]{3}{*}{$\begin{array}{l}\text { Prelusky } \\
\text { et al., } 1990 \mathrm{~b}\end{array}$} \\
\hline & $1.8 \mathrm{~g} \mathrm{ZON}$ & $\begin{array}{l}\text { Single } \\
\text { dose }\end{array}$ & Serum & $\begin{array}{l}\mathrm{t}_{\max } / \mathrm{C}_{\max }: \mathrm{ZON} \text { (conjugated): } 12 \mathrm{~h} \text { (post dosing) } \\
=9 \mathrm{ng} / \mathrm{ml}\end{array}$ & \\
\hline & $6.0 \mathrm{~g} \mathrm{ZON}$ & $\begin{array}{l}\text { Single } \\
\text { dose }\end{array}$ & Serum & $\begin{array}{l}\mathrm{t}_{\max } / \mathrm{C}_{\max }: \mathrm{ZON} \text { (conjugated): } 12 \mathrm{~h} \text { (post dosing) } \\
=13 \mathrm{ng} / \mathrm{ml}\end{array}$ & \\
\hline \multirow[t]{6}{*}{ Heifer } & $158 \mu \mathrm{g} /$ animal & 84 & Urine & $\mathrm{ZON}$ and $\beta-\mathrm{ZOL}:<0.5 \mu \mathrm{g} / \mathrm{l}$ & \multirow{6}{*}{$\begin{array}{l}\text { Kleinova } \\
\text { et al., } 2002\end{array}$} \\
\hline & \multirow{3}{*}{$\begin{array}{l}2740 \mu \mathrm{g} / \\
\text { animal }\end{array}$} & \multirow{3}{*}{84} & Liver & $\beta-\mathrm{ZOL}<1.0 \mu \mathrm{g} / \mathrm{kg}$ & \\
\hline & & & Urine & $\begin{array}{l}\text { ZON 5-8, } \alpha-Z O L ~ 3-5, \beta-Z O L ~ 20-65, \alpha-Z A L \\
2-3, \beta-Z A L<0.5 \mu \mathrm{g} / 1\end{array}$ & \\
\hline & & & Liver & $\begin{array}{l}\mathrm{ZON} \text { and } \alpha-\mathrm{ZOL}<0.5-1.2, \beta-\mathrm{ZOL} 5-11.5 \\
\mu \mathrm{g} / \mathrm{kg}\end{array}$ & \\
\hline & $\begin{array}{l}2 \times 25 \mathrm{mg} \\
\alpha \text {-ZAL pellets } \\
+158 \mu \mathrm{g} / \\
\text { animal } / \mathrm{d}\end{array}$ & 84 & Urine & $\begin{array}{l}\mathrm{ZON} \text { and } \alpha-\mathrm{ZOL}<0.5, \alpha-\mathrm{ZAL} 2-5, \beta-\mathrm{ZAL}< \\
0.5 \mu \mathrm{g} / \mathrm{l}\end{array}$ & \\
\hline & & & & $\begin{array}{l}\rightarrow 80 \% \text { of the analysed } \mathrm{ZON} \text { in urine and } \\
\text { tissue samples was transformed to } \beta-\mathrm{ZOL}\end{array}$ & \\
\hline $\begin{array}{c}\text { Growing } \\
\text { bull }\end{array}$ & $\begin{array}{c}0.1 \mathrm{mg} \mathrm{ZON} / \\
\mathrm{kg}\end{array}$ & $152-160$ & Bile & $\begin{array}{l}\text { ZON } 7-24, \alpha-Z O L 2-11, \beta-Z O L 23-53 \mathrm{ng} / \mathrm{g} \\
\text { ZAL }<100, \alpha-Z A L<50, \beta-Z A L<200 \mathrm{ng} / \mathrm{g} \\
\rightarrow \beta-Z \mathrm{Z}, \mathrm{ZON} \text { and } \alpha-Z \mathrm{OL} \text { amounted } 68,24 \\
\text { and } 8 \% \text { of total metabolites }\end{array}$ & $\begin{array}{l}\text { Dänicke et } \\
\text { al., 2002a }\end{array}$ \\
\hline $\begin{array}{l}\text { Dairy } \\
\text { cow }\end{array}$ & $\begin{array}{c}0.76 \mathrm{mg} \\
\mathrm{ZON} / \mathrm{kg} \\
\text { wheat }\end{array}$ & 35 & $\begin{array}{c}\text { Duodenal } \\
\text { chyme }\end{array}$ & $\begin{array}{l}\rightarrow \mathrm{ZON}, \alpha-\mathrm{ZOL} \text { and } \beta-\mathrm{ZOL} \text { flow at the } \\
\text { duodenum }(\% \text { of } \mathrm{ZON} \text { intake): } \\
43-132 \%\end{array}$ & $\begin{array}{l}\text { Dänicke et } \\
\text { al., } 2005\end{array}$ \\
\hline
\end{tabular}

$\mathrm{ZON}=$ zearalenone, $\alpha$-ZOL $=\alpha$-zearalenol, $\beta$-ZOL $=\beta$-zearalenol, $\mathrm{ZAL}=$ zearalanone; $\alpha-\mathrm{ZAL}=$ zeranol; $\beta-\mathrm{ZAL}=$ taleranol; $\mathrm{C}_{\max }=$ maximal concentration; $\mathrm{t}_{\max }=$ time of the maximal concentration 
Company, USA), was detected in $6.6 \%$ of these samples. The authors suggest that the formation of $\alpha$-ZAL may occur primarily via reduction of $\alpha-Z O L$, probably in the reductive environment of the rumen. The results are in agreement with earlier investigations which implied that $\alpha$-ZAL can occur in domestic animals without deliberate $\alpha$-ZAL treatment (Erasmuson et al., 1994; Kennedy et al., 1995; Miles et al., 1996; Figure 2). Moreover, Kennedy et al. (1998) found significantly higher $\alpha$-ZOL (12-fold) and $\beta$-ZOL (9-fold) concentrations in the $\alpha$-ZAL positive samples than in the $\alpha$-ZAL negative samples with an $\alpha$-ZAL: $\alpha$-ZOL ratio of at least 1:5. Therefore, the authors suggested using the ratio for a control of the $\alpha-Z O L$ ban, because it is unlikely that an $\alpha$-ZAL: $\alpha$-ZOL ratio of less than 1:5 occurs under field conditions. Kleinova et al. (2002) only detected the metabolites $\alpha$-ZAL, $\beta$-ZAL and ZAN in the urine whereas the ratio between $\alpha-Z A L$ or $\beta-Z A L$ and $\beta-Z O L$ varied between 1:8 and 1:26. Dänicke et al. (2005), who fed fistulated dairy cows with Fusarium toxin contaminated wheat $(0.26$ and $0.10 \mathrm{mg} Z \mathrm{ZON} / \mathrm{kg}$ wheat $)$ over a $35 \mathrm{~d}$ period, reported on mean proportions of $\alpha-Z O L, \beta-Z O L$ and ZON of the sum of these substances at the duodenum of 30, 40 and $30 \%$, however $\alpha$-ZAL, $\beta$-ZAL and ZAN residues were below the detection limits. Moreover, the high recovery of ZON plus metabolites (89\%) at the duodenum would imply a rather low complete degradation of $\mathrm{ZON}$ in the rumen and/or recovery of some bile-originating enterohepatic-cycling ZON/metabolites (Dänicke et al., 2005).

In addition, $Z O N$ and its metabolites have been shown to carry over into ruminant milk (Table 6 ). Total residues (ZON, $\alpha$-ZOL and $\beta$-ZOL, conjugated and free) of $1.4 \mathrm{mg} / \mathrm{l}$ corresponding to $0.7 \%$ of the consumed $Z O N$ were detected in cow milk after feeding a ZON concentration of $25 \mathrm{mg} / \mathrm{kg}$ diet for 7 days (Mirocha et al., 1981). Only $27 \%$ of the total metabolites (free and conjugated) occurred as $\beta-Z O L$, while 35 and $37 \%$ appeared as ZON and $\alpha-Z O L$. However, Prelusky et al. (1990) found concentrations of total residues mainly containing ZON and $\alpha-Z O L$ conjugates less than $6 \mu \mathrm{g} / \mathrm{kg}$ in milk from a cow that consumed $545 \mathrm{mg} \mathrm{ZON} / \mathrm{d}$ for 21 days. Also, single ZON administrations of 1800 or $6000 \mathrm{mg}$ given over one day resulted only in trace concentrations of the total residues. Similarly, low traces of ZON and $\beta$-ZOL were measured in milk in a study by Hagler et al. (1980) who fed a single dose of $5000 \mathrm{mg} Z \mathrm{ZON}$ to one cow. The capacity of the rumen microorganisms to degrade $\mathrm{ZON}$ was discussed as one reason for the widespread discrepancies between the single results of the studies (Prelusky et al., 1990). No residues or only traces were accordingly detected after administration of low ZON doses (Prelusky et al., 1990; Usleber et al., 1992; Goll et al., 1995). Furthermore, only little information is available on ZON residues in edible tissues. In studies by Shreeve et al. (1979) and Dänicke et al. (2002a) residues in muscle, liver, kidney, fat from kidney cavity and back fat were below the detection limits. Also, Kleinova et al. (2002) found no residues in muscle tissues of heifers, which were 
TABLE 6

Zearalenone (ZON) dose and ZON and metabolites in milk and edible tissues of ruminants (according to Dänicke et al., 2000)

\begin{tabular}{|c|c|c|c|c|c|}
\hline \multirow{3}{*}{$\begin{array}{l}\text { Animal } \\
\text { species }\end{array}$} & \multirow{3}{*}{$\begin{array}{l}\text { Dose } \\
\mathrm{mg} / \mathrm{kg} \text { diet }\end{array}$} & \multirow{3}{*}{$\begin{array}{l}\text { Duration } \\
\text { day }\end{array}$} & \multirow{2}{*}{\multicolumn{2}{|c|}{$\begin{array}{c}\text { Toxins and metabolites in milk and eatable } \\
\text { tissues }\end{array}$}} & \multirow{3}{*}{ Literature } \\
\hline & & & & & \\
\hline & & & Tissue & $\begin{array}{l}\text { Concentration and/or distribution of } \\
\text { DON and metabolites }\end{array}$ & \\
\hline $\begin{array}{l}\text { Dairy } \\
\text { cow }\end{array}$ & $\begin{array}{l}0.39-1.93 \mathrm{mg} / \\
\mathrm{kg} \text { concentrate }\end{array}$ & 49 & $\begin{array}{l}\text { Muscle } \\
\text { Liver } \\
\text { Kidney } \\
\text { Milk }\end{array}$ & $\mathrm{ZON}<4 \mu \mathrm{g} / \mathrm{l}$ and $\mu \mathrm{g} / \mathrm{kg}$, respectively & $\begin{array}{l}\text { Shreeve et } \\
\text { al., } 1979\end{array}$ \\
\hline $\begin{array}{l}\text { Dairy } \\
\text { cow }\end{array}$ & $5000 \mathrm{mg} /$ animal & $\begin{array}{l}\text { Single } \\
\text { dose }\end{array}$ & Milk & $\begin{array}{l}\mathrm{ZON} \text { and } \beta-\mathrm{ZOL}<1 \mu \mathrm{g} / 1 \\
\text { (incubation with } \beta \text {-glucuronidase) }\end{array}$ & $\begin{array}{l}\text { Hagler et } \\
\text { al., } 1980\end{array}$ \\
\hline Sheep & $1800 \mathrm{mg} /$ animal & $\begin{array}{l}\text { Single } \\
\text { dose }\end{array}$ & Milk & $\begin{array}{l}\mathrm{ZON} \text { and } \beta \text {-ZOL } 1-2 \mu \mathrm{g} / 1 \\
\text { (incubation with } \beta \text {-glucuronidase) }\end{array}$ & $\begin{array}{l}\text { Hagler et } \\
\text { al., } 1980\end{array}$ \\
\hline $\begin{array}{l}\text { Dairy } \\
\text { cow }\end{array}$ & 25 & 7 & Milk & $\begin{array}{l}1360 \mu \mathrm{g} / 1 \text { total-residuals (conjugated } \\
\text { and free) } \\
\rightarrow 0.7 \% \text { of the } \mathrm{ZON} \text { recovered in } \\
\text { the milk }\end{array}$ & $\begin{array}{l}\text { Mirocha et } \\
\text { al., } 1981\end{array}$ \\
\hline \multirow[t]{3}{*}{$\begin{array}{l}\text { Dairy } \\
\text { cow }\end{array}$} & $\begin{array}{l}50 \text { and } 165 \\
\mathrm{mg} / \mathrm{d}\end{array}$ & 21 & Milk & $\begin{array}{l}\mathrm{ZON}, \alpha-\mathrm{ZOL} \text { and } \beta-\mathrm{ZOL} \text { as well as } \\
\text { conjugates }<0.5,<0.5 \text { and }<1.5 \mu \mathrm{g} / 1\end{array}$ & \multirow[t]{3}{*}{$\begin{array}{l}\text { Prelusky } \\
\text { et al., } 1990\end{array}$} \\
\hline & $545 \mathrm{mg} / \mathrm{d}$ & 21 & Milk & $\begin{array}{l}\mathrm{C}_{\text {max }}: \mathrm{ZON} \text { and } \alpha-\mathrm{ZOL} \text { (only as } \\
\text { conjugates) } 2.5 \text { and } 3.0 \mu \mathrm{g} / 1\end{array}$ & \\
\hline & $\begin{array}{l}1800 \text { and } 6000 \\
\mathrm{mg} / \text { animal }\end{array}$ & $\begin{array}{l}\text { Single } \\
\text { dose }\end{array}$ & Milk & $\begin{array}{l}\mathrm{C}_{\max }: \mathrm{ZON} 4.0 \text { and } 6.1 ; \alpha-\mathrm{ZOL} 1.5 \text { and } \\
4.0 ; \beta \text {-ZOL } 4.1 \text { and } 6.6 \mu \mathrm{g} / 1\end{array}$ & \\
\hline $\begin{array}{l}\text { Dairy } \\
\text { cow }\end{array}$ & $\begin{array}{l}25 \text { and } 100 \\
\mathrm{mg} / \text { day }\end{array}$ & 6 & Milk & $\begin{array}{l}\mathrm{C}_{\text {max }}: \mathrm{ZON} \text {-equivalent } 0.4 \text { and } 1.2 \mu \mathrm{g} / \mathrm{l} \text {, } \\
\text { respectively (determination with Elisa } \\
\text { after incubation with } \beta \text {-glucuronidase, } \\
\text { particularly detection of } \alpha \text { - and } \beta \text {-ZOL) }\end{array}$ & $\begin{array}{l}\text { Usleber et } \\
\text { al., } 1992\end{array}$ \\
\hline $\begin{array}{l}\text { Dairy } \\
\text { cow }\end{array}$ & $0.02-0.05$ & 63 & Milk & $\mathrm{ZON}$ and $\alpha-\mathrm{ZOL}<0.5 \mu \mathrm{g} / 1$ & $\begin{array}{l}\text { Goll et al., } \\
1995\end{array}$ \\
\hline \multirow[t]{3}{*}{ Heifers } & $158 \mu \mathrm{g} /$ animal & 84 & Liver & $\beta-\mathrm{ZOL}<1 \mu \mathrm{g} / \mathrm{kg}$ & \multirow{3}{*}{$\begin{array}{l}\text { Kleinova } \\
\text { et al., } 2002\end{array}$} \\
\hline & $2740 \mu \mathrm{g} /$ animal & 84 & Liver & $\begin{array}{l}\mathrm{ZON}<1.0-2.1 ; \alpha-\mathrm{ZOL}<1.0-2.4 ; \beta- \\
\mathrm{ZOL} 5.0-11.5 \mu \mathrm{g} / \mathrm{kg}\end{array}$ & \\
\hline & $\begin{array}{l}2 \times 25 \mathrm{mg} \\
\text { zeranol pellets }+ \\
158 \mu \mathrm{g} / \text { animal } / \mathrm{d}\end{array}$ & 84 & Liver & No traces of ZAL, $\alpha$-ZAL, $\beta$-ZAL & \\
\hline $\begin{array}{l}\text { Growing } \\
\text { bull }\end{array}$ & $0.1 \mathrm{mg} / \mathrm{kg}$ & $152-160$ & $\begin{array}{l}\text { Muscle } \\
\text { Liver } \\
\text { Kidney } \\
\text { Back fat }\end{array}$ & $\begin{array}{l}\mathrm{ZON}, \alpha-\mathrm{ZOL}, \beta-\mathrm{ZOL}, \mathrm{ZAN}, \alpha-\mathrm{ZAL}, \\
\beta-\mathrm{ZAL}<1,<0.5,<5,<100,<50,< \\
200 \mathrm{ng} / \mathrm{g}\end{array}$ & $\begin{array}{l}\text { Dänicke et } \\
\text { al., 2002a }\end{array}$ \\
\hline
\end{tabular}

ZON $=$ zearalenone, $\alpha$-ZOL $=\alpha$-zearalenol, $\beta$-ZOL $=\beta$-zearalenol, $\mathrm{ZAL}=$ zearalanone; $\alpha$ $\mathrm{ZAL}=$ zeranol; $\beta-\mathrm{ZAL}=$ taleranol; $\mathrm{C}_{\max }=$ maximal concentration; $\mathrm{t}_{\max }=$ time of the maximal concentration 
fed with oat diets containing $1370 \mu \mathrm{g} / \mathrm{kg} \mathrm{ZON}$ for 84 days. However, in the liver samples of the same animals, $\beta$-ZOL $(5.0-11.5 \mu \mathrm{g} / \mathrm{kg}), \alpha-Z O L(<1.0-2.4 \mu \mathrm{g} / \mathrm{kg})$ and $\mathrm{ZON}(<1.0-2.1 \mu \mathrm{g} / \mathrm{kg})$ could be identified.

\section{DEOXYNIVALENOL AND ZEARALENONE EFFECTS ON HEALTH AND PERFORMANCE IN DEPENDENCE ON DOSAGE AND DURATION OF TOXIN EXPOSURE}

\section{Deoxynivalenol}

Noller et al. (1979) fed Gibberella zeae infected maize in complete mixed rations to lactating dairy cows and found a slight decrease of daily feed intake with a concomitant decrease of body weight gain, but milk fat and milk production did not differ. The maize offered to the cows was not analysed for DON, however pigs refused the ingestion of this maize-batch. Therefore, the authors supposed the existence of DON in the maize. In agreement with these results, Trenholm et al. (1985) noticed that feed intake was slightly reduced when naturally contaminated grain was added to the ration of non lactating cows. However, no clinical symptoms of illness could be observed that might be attributed to the DON concentration of 1.5 up to $6.4 \mathrm{mg} / \mathrm{kg}$.

Short-term feeding of very high DON concentrations of $66 \mathrm{mg} / \mathrm{kg}$ diet during a five day trial affected neither feed intake nor the milk production (Cote et al., 1986). Also, feeding of diets containing DON concentrations of 6 or $12 \mathrm{mg} / \mathrm{kg}$ to low-producing dairy cows in a 10 week long-term study did not affect the intake of concentrate or forage (Charmley et al., 1993). It is unlikely that the marked reduction in fat content of the milk and the tendency toward lower fat corrected milk production, when the DON concentration of $6 \mathrm{mg} / \mathrm{kg}$ was fed, was caused by the presence of DON, because the effect was not induced by feeding the higher DON concentration of $12 \mathrm{mg} / \mathrm{kg}$. Accordingly, Ingalls et al. (1996) observed no effects on milk performance, milk composition and milk fat amount when feeding DON concentrations up to $14.6 \mathrm{mg} / \mathrm{kg}$ concentrate during 21 days. However, Whitlow et al. (1986) found a declined milk production in dairy cow herds when DON concentration in grain increased.

For fattened beef cattle, Schuh (1996) suggested that a chronic exposure with a DON concentration up to $0.5 \mathrm{mg} / \mathrm{kg}$ ration would adversely affect performance and cause a decreased feed intake, a lower weight gain and abnormal hair growth. DeHaan et al. (1983) evaluated effects of DON ingestion on feedlot steer, heifer and fattening lamb performance. The authors reported that the presence of DON at a concentration of $1 \mathrm{mg} / \mathrm{kg}$ diet given to steers as well as heifers during a 142 
day experiment had no deleterious effects on average daily gain, feed intake, feed efficiency and carcass characteristics. Feeding scabby wheat ( $8.5 \mathrm{mg}$ DON/kg diet) to fattening lambs appeared not to affect feedlot performance. Also, performance data of lambs, which were fed a diet containing DON concentrations of 15.6 $\mathrm{mg} / \mathrm{kg}$ for 28 days, did not differ from those of the controls (Harvey et al., 1986). In a more extensive study, Nelson et al. (1984) evaluated the effects of a DON contaminated wheat diet $(2.3$ and $10.0 \mathrm{mg} / \mathrm{kg})$ or a DON contaminated maizebased diet $(0.2 \mathrm{mg} / \mathrm{kg})$ on performance, toxicity and pathologic changes in steers and heifers. No adverse effects of DON on tissue histology, serum biochemistry, white blood cell differential count, or glucose, urea, creatinine, calcium, phosphor, sodium and potassium content in blood were observed. Also, DiCostanzo et al. (1995) indicated that feeding dietary DON up to $190.8 \mathrm{mg} / \mathrm{d}$ for 135 days did not affect intake, daily gain, feed efficiency and carcass characteristics, serum biochemistry and haematological variables of steers. Comparable results were obtained by recent feeding experiments using feedlot steers consuming dietary DON concentrations up to $221.9 \mathrm{mg} / \mathrm{d}$ (Boland et al., 1994; Windels et al., 1995; Dupchak, 1998). In a study of Anderson et al. (1995), who investigated the impact of DON contaminated barley $(36.8 \mathrm{mg} / \mathrm{kg})$ fed to yearling heifers during mid and late gestation on pregnancy and birth, no differences in feed intake, cow weight gain or calf birth weight were observed. However, calves nursing cows of the DON contaminated diet during the first 45 days of lactation showed significantly higher gains.

Moreover, numerous studies have been carried out where more than only DON as prevalent toxin in a significant concentration was detected in the feed. Thereby it is difficult to distinguish whether the observed effects are caused by DON alone or by interactions between the toxins. Schuh and Baumgartner (1988) reported diarrhoea in steers fed a diet containing $14.5 \mathrm{mg} \mathrm{DON} / \mathrm{kg}$ and $4.5 \mathrm{mg}$ $\mathrm{T} 2 / \mathrm{kg}$. Whether this effect was caused by DON, T2 or the interaction is not clear. In another study, Hochsteiner et al. (2000) investigated the effect of naturally DON and ZON contaminated feed on dairy cows. The average daily DON and ZON intake ranged from 12.4 to $14.3 \mathrm{mg}$ and 0.67 to $0.94 \mathrm{mg}$, respectively. No significant differences could be observed regarding the milk yield and milk ingredients between the different mycotoxin concentrations. Additionally, the enzymes gamma glytamyl transferase and alkalic phosphatase and the metabolites glucose, urea, creatinine and bilirubin in the serum were in the normal range, while slightly increased aspartate aminotransferase and glutamate dehydrogenase activities were determined. In contrast, in an experiment by Dänicke et al. (2002a), who fed growing bulls with Fusarium contaminated wheat (10 mg DON and 0.76 mg ZON per kg dry matter), the serum activities of aspartate aminotransferase and glutamate dehydrogenase were unaffected by dietary treatment. However, the 
serum cholesterol levels were slightly decreased but the authors noted that this observation is difficult to explain due to the complicated cholesterol metabolism. No explanation could be given for the significantly increased weights of the empty gastrointestinal tract, the significantly decreased empty body weights and the decreased dressing percentages of the slaughtered bulls fed the Fusarium toxin contaminated concentrate. With regard to the oestrogenic properties of ZON, weights of the testicles were slightly reduced due to feeding the toxin contaminated concentrate, which possibly indicates an endocrine alteration (Dänicke et al., 2002a).

Furthermore, antimicrobial properties of the mycotoxins, which possibly affect fermentative capacity of the rumen, were observed in a vitro study. A decreased volatile fatty acids production and a reduction in gas production were observed with mouldy maize silage in an in vitro study using the rumen simulation technique RUSITEC (Maiworm et al., 1995). However, Westlake et al. (1987a, b) tested the influence of the Fusarium toxins DON and T2 on the growth of the rumen bacteria Butyrivibrio fibrisolvens and observed no inhibitory effect. Rumen physiological investigations including wethers have shown that rumen $\mathrm{pH}$ and concentrations of ammonia and volatile fatty acids were not influenced due to feeding a ration of hay and Fusarium contaminated wheat (4.6 mg of DON and $0.34 \mathrm{mg}$ ZON per kg of complete ration on dry matter) (Dänicke, 2002b). Also, no impact of feeding DON and ZON contaminated wheat on $\mathrm{pH}$-value and the concentration of volatile fatty acids in rumen fluid of fistulated dairy cows was observed in studies by Dänicke et al. (2005). However, the ruminal ammonia concentration was higher when the contaminated wheat was fed (Dänicke et al., 2005), while the duodenal flow of microbial protein (Dänicke et al., 2005) and of undegraded dietary protein were reduced (Dänicke et al., 2005; Seeling et al., 2005). The authors suggested that the altered ruminal protein utilization could possibly results from the modified chemical and physical properties of the grain caused by the fungal invasion. Higher protease activity, increases in the soluble protein fraction and in the non starch polysaccharide hydrolysing enzyme activities accompanied with significantly reduced cell wall compounds cellulose, xylan and pectin were found in Fusarium contaminated wheat (Kang and Buchenauer, 2000; Matthäus et al., 2004; Dänicke et al., 2005). 


\section{Zearalenone}

Mirocha et al. (1968) reported a case study in England where the insemination index increased from 1.2 to 4 when hay of poor quality was fed to a herd of 150 dairy cattle. Analyses of a hay sample resulted in a ZON concentration of $14 \mathrm{mg} /$ $\mathrm{kg}$. The insemination index returned to normal after the hay was replaced. Roine et al. (1971) described a clinical picture with vulva and vagina swelling, abundant mucous discharge from the vulva and false oestrus by dairy cows. Fusarium graminearum and Fusarium culmorum were isolated from the meal feed and due to their ability to produce considerable amounts of $\mathrm{ZON}$ in vitro, the authors deduced that the fertility disturbances were caused by ZON. Vulva swelling, reduced milk performance and reduced appetite of dairy cows were observed by Vanyi et al. (1974). The concentration of ZON in the feed amounted up to $75 \mathrm{mg} / \mathrm{kg}$. Furthermore, large doses of ZON were associated with abortions in cattle (Kallela and Ettala, 1984). The presence of ZON at a concentration of $1 \mathrm{mg} / \mathrm{kg}$ in a ration of dairy cows was associated with feed refusal, lethargy and anaemia (Mirocha, 1974). In another case report, 2 out of 20 heifers had enlarged mammary glands and the mammary secretion resembled skim milk although the heifers were not pregnant and no oestrus was observed (Bloomquist et al., 1982). The fed maize was covered with a fungal-like growth and a sample was found positive for ZON (no data on concentrations). Epidemiological studies of Schuh $(1981,1983)$ indicated that ZON contaminated wheat $(1.25 \mathrm{mg} / \mathrm{kg})$ fed to dairy cattle led to cystic degeneration of ovaries and to alterations in the consistence of the uterus. Coppock et al. (1990) reported on a herd of dairy cows and replacement heifers which were fed with a ration containing $1.5 \mathrm{mg} \mathrm{ZON}$ and $1.0 \mathrm{mg} \mathrm{DON} / \mathrm{kg}$. Cows showed frequent episodes of false oestrus of 2 to $5 \mathrm{~d}$ duration and idiopathic vaginitis. Furthermore, mammary gland enlargement was observed in the prepubertal heifers. In a study by Möser (2001), heifers were fed with Fusarium contaminated ground oats (1.25 $\mathrm{mg} \mathrm{ZON} / \mathrm{kg}$ ), while a second group was given a zeranol implant (Ralgro ${ }^{\circledR}$ ) twice at intervals of 6 weeks. The animals fed with the contaminated oats showed a higher mean daily weight gain. However, neither any disturbance of the oestrous cycle nor any pathological or histological changes in the reproductive organs were observed due to the influence of ZON and zeranol. 
TABLE 7

Effects of the Fusarium toxins deoxynivalenol (DON) and zearalenone (ZON) on ruminant performance

\begin{tabular}{|c|c|c|c|c|}
\hline Toxin & $\begin{array}{l}\text { Animal } \\
\text { species }\end{array}$ & Experimental description & Symptoms & Literature \\
\hline DON & $\begin{array}{l}\text { Dairy } \\
\text { cow }\end{array}$ & $\begin{array}{l}\text { Maize was not analysed for } \\
\text { DON; however pigs refused } \\
\text { ingestion of the maize batch, } \\
\text { so that authors supposed } \\
\text { the existence of DON in the } \\
\text { maize }\end{array}$ & $\begin{array}{l}\text { Slight decrease of daily } \\
\text { feed intake } \\
\text { No differences in milk } \\
\text { fat and milk production }\end{array}$ & $\begin{array}{l}\text { Noller et al., } \\
1979\end{array}$ \\
\hline \multirow[t]{2}{*}{ DON } & $\begin{array}{l}\text { Heifer } \\
\text { Steer }\end{array}$ & $1 \mathrm{mg} / \mathrm{kg}$ diet during 142 days & $\begin{array}{l}\text { No differences in animal } \\
\text { performance or carcass } \\
\text { characteristics }\end{array}$ & $\begin{array}{l}\text { DeHaan et al., } \\
1983\end{array}$ \\
\hline & $\begin{array}{l}\text { Fattening } \\
\text { lamb }\end{array}$ & $8.5 \mathrm{mg} / \mathrm{kg}$ diet during 45 days & $\begin{array}{l}\text { No effect on animal } \\
\text { performance }\end{array}$ & \\
\hline DON & $\begin{array}{l}\text { Steer } \\
\text { Heifer }\end{array}$ & $\begin{array}{l}0.2,2.3 \text { and } 10 \mathrm{mg} / \mathrm{kg} \text { during } \\
126 \text { days }\end{array}$ & $\begin{array}{l}\text { No apparent clinical } \\
\text { signs or toxic } \\
\text { manifestations } \\
\text { No toxicological or } \\
\text { pathological changes } \\
\text { by serum and whole } \\
\text { blood profiles }\end{array}$ & $\begin{array}{l}\text { Nelson et al., } \\
1984\end{array}$ \\
\hline DON & $\begin{array}{l}\text { Dairy } \\
\text { cow }\end{array}$ & $\begin{array}{l}1.5 \mathrm{mg} / \mathrm{kg} \text { during } 28 \text { days and } \\
6.4 \mathrm{mg} / \mathrm{kg} \text { during } 70 \text { days }\end{array}$ & $\begin{array}{l}\text { Replacing the lower } \\
\text { with the higher DON } \\
\text { contaminated feed } \\
\text { caused temporary lower } \\
\text { feed intakes }\end{array}$ & $\begin{array}{l}\text { Trenholm et al., } \\
1985\end{array}$ \\
\hline DON & $\begin{array}{l}\text { Dairy } \\
\text { cow }\end{array}$ & 0 to $0.8 \mathrm{mg} / \mathrm{kg}$ concentrate & $\begin{array}{l}\text { Milk production } \\
\text { decreased when feeding } \\
\text { the higher DON } \\
\text { contaminated concentrate }\end{array}$ & $\begin{array}{l}\text { Whitlow et al., } \\
1986\end{array}$ \\
\hline DON & $\begin{array}{l}\text { Dairy } \\
\text { cow }\end{array}$ & $66 \mathrm{mg} / \mathrm{kg}$ during 5 days & $\begin{array}{l}\text { No differences in } \\
\text { feed intake or milk } \\
\text { production }\end{array}$ & Cote et al., 1986 \\
\hline DON & Lamb & $\begin{array}{l}15.6 \mathrm{mg} / \mathrm{kg} \text { diet during } 28 \\
\text { days }\end{array}$ & $\begin{array}{l}\text { No differences in feed } \\
\text { consumption, weight } \\
\text { gains or feed efficiency } \\
\text { No differences in } \\
\text { haematological or serum } \\
\text { biochemical variables }\end{array}$ & $\begin{array}{l}\text { Harvey et al., } \\
1986\end{array}$ \\
\hline DON & $\begin{array}{l}\text { Dairy } \\
\text { cow }\end{array}$ & $\begin{array}{l}6 \mathrm{mg} / \mathrm{kg} \text { or } 12 \mathrm{mg} / \mathrm{kg} \\
\text { concentrate during } 70 \text { days }\end{array}$ & $\begin{array}{l}\text { No effects on feed intake } \\
\text { and milk performance }\end{array}$ & $\begin{array}{l}\text { Charmley et al., } \\
1993\end{array}$ \\
\hline
\end{tabular}


TABLE 7 Continued

\begin{tabular}{|c|c|c|c|c|}
\hline Toxin & $\begin{array}{l}\text { Animal } \\
\text { species }\end{array}$ & Experimental description & Symptoms & Literature \\
\hline DON & Steer & $\begin{array}{l}\text { Growing period ( } 84 \text { days): } \\
0.9,3.7,6.4,9.2 \mathrm{mg} / \mathrm{kg} \text { diet } \\
\text { Finishing period ( } 100 \text { days): } \\
1.1,5.0,8.8,12.6 \mathrm{mg} / \mathrm{kg} \text { diet }\end{array}$ & $\begin{array}{l}\text { No differences for } \\
\text { carcass weight, } \\
\text { dressing percentage, fat } \\
\text { thickness, yield grade } \\
\text { and quality grade } \\
\text { No differences in feed } \\
\text { intake, feed efficiency } \\
\text { and weight gain }\end{array}$ & $\begin{array}{l}\text { Boland et al., } \\
1994\end{array}$ \\
\hline DON & Heifer & $36.8 \mathrm{mg} / \mathrm{kg}$ barley & $\begin{array}{l}\text { No differences in feed } \\
\text { intake, weight gain, calf } \\
\text { birth weights or blood } \\
\text { parameters }\end{array}$ & $\begin{array}{l}\text { Anderson et al., } \\
1995\end{array}$ \\
\hline DON & Steer & $\begin{array}{l}0,63.6,127.1 \text { and } 190.8 \mathrm{mg} / \mathrm{d} \\
\text { during } 135 \text { days }\end{array}$ & $\begin{array}{l}\text { No effect on feed } \\
\text { consumption, live- } \\
\text { weight gain and carcass } \\
\text { composition }\end{array}$ & $\begin{array}{l}\text { Dicostanzo et al. } \\
1995\end{array}$ \\
\hline DON & Steer & $\begin{array}{l}0,73.3,145.2 \text { and } 221.9 \mathrm{mg} / \mathrm{d} \\
\text { during } 144 \text { days }\end{array}$ & $\begin{array}{l}\text { No effect on intake, } \\
\text { daily gain, feed } \\
\text { efficiency and carcass } \\
\text { characteristics, serum } \\
\text { biochemistry and } \\
\text { haematological variables }\end{array}$ & $\begin{array}{l}\text { Windels et al., } \\
1995\end{array}$ \\
\hline DON & $\begin{array}{l}\text { Dairy } \\
\text { cow }\end{array}$ & $\begin{array}{l}\text { Up to } 14.6 \mathrm{mg} / \mathrm{kg} \text { concentrate } \\
\text { during } 21 \text { days }\end{array}$ & $\begin{array}{l}\text { No effects on } \\
\text { feed intake, milk } \\
\text { performance, milk } \\
\text { composition and milk } \\
\text { fat amount }\end{array}$ & $\begin{array}{l}\text { Ingalls et al., } \\
1996\end{array}$ \\
\hline DON & Steer & 9 to $15 \mathrm{mg} / \mathrm{kg}$ ration & $\begin{array}{l}\text { No effects on feed } \\
\text { intake, weight gain or } \\
\text { feed to gain ratio }\end{array}$ & Dupchak, 1998 \\
\hline DON & $\begin{array}{l}\text { Dairy } \\
\text { cow }\end{array}$ & $\begin{array}{l}4.5 \mathrm{mg} \text { estimated daily } \\
\text { exposure }\end{array}$ & $\begin{array}{l}\text { Decreased red and white } \\
\text { blood counts } \\
\text { Increased serum } \\
\text { activities of GLDH }\end{array}$ & $\begin{array}{l}\text { Sabater Vilar, } \\
2003\end{array}$ \\
\hline $\mathrm{ZON}$ & $\begin{array}{l}\text { Dairy } \\
\text { cow }\end{array}$ & $\begin{array}{l}\text { Determination of ZON (14 } \\
\mathrm{mg} / \mathrm{kg}) \text { in hay }\end{array}$ & $\begin{array}{l}\text { Increased insemination } \\
\text { index }(1.2 \text { to } 4)\end{array}$ & $\begin{array}{l}\text { Mirocha et al., } \\
1968\end{array}$ \\
\hline $\mathrm{ZON}$ & $\begin{array}{l}\text { Dairy } \\
\text { cow }\end{array}$ & $\begin{array}{l}\text { Determination of Fusarium } \\
\text { graminearum and Fusarium } \\
\text { culmorum, which synthesised } \\
\text { ZON in vitro }\end{array}$ & $\begin{array}{l}\text { Vulva swelling } \\
\text { False oestrus } \\
\text { Mucus vaginal discharge }\end{array}$ & $\begin{array}{l}\text { Roine et al., } \\
1971\end{array}$ \\
\hline $\mathrm{ZON}$ & $\begin{array}{l}\text { Dairy } \\
\text { cow }\end{array}$ & 5 up to $75 \mathrm{mg} / \mathrm{kg}$ & $\begin{array}{l}\text { Vulva swelling } \\
\text { Reduced milk } \\
\text { performance } \\
\text { Reduced appetite }\end{array}$ & $\begin{array}{l}\text { Vanyi et al., } \\
1974\end{array}$ \\
\hline $\mathrm{ZON}$ & $\begin{array}{l}\text { Dairy } \\
\text { cow }\end{array}$ & $1 \mathrm{mg} / \mathrm{kg}$ & $\begin{array}{l}\text { Presence of ZON was } \\
\text { associated with feed } \\
\text { refusal, lethargy and } \\
\text { anaemia }\end{array}$ & Mirocha, 1974 \\
\hline
\end{tabular}


TABLE 7 Continued

\begin{tabular}{|c|c|c|c|c|}
\hline Toxin & $\begin{array}{l}\text { Animal } \\
\text { species }\end{array}$ & Experimental description & Symptoms & Literature \\
\hline ZON & $\begin{array}{l}\text { Dairy } \\
\text { cow }\end{array}$ & $1.25 \mathrm{mg} / \mathrm{kg}$ & $\begin{array}{l}\text { Cystic degeneration of } \\
\text { the ovaries } \\
\text { Consistence alterations } \\
\text { of the uterus }\end{array}$ & $\begin{array}{l}\text { Schuh, 1981, } \\
1983\end{array}$ \\
\hline $\mathrm{ZON}$ & Heifer & $\begin{array}{l}\text { Determination of ZON in } \\
\text { mouldy maize (no data about } \\
\text { concentrations) }\end{array}$ & $\begin{array}{l}\text { Bagging up although } \\
\text { not pregnant and no } \\
\text { oestrus } \\
\text { Growth increase } \\
\text { Secret similarly milk }\end{array}$ & $\begin{array}{l}\text { Bloomquist et } \\
\text { al., } 1982\end{array}$ \\
\hline ZON & Ewe & $\begin{array}{l}25 \mathrm{mg} \text { purified } \mathrm{ZON} / \mathrm{d} \text { or } \\
\text { Fusarium culture (contained } \\
25 \mathrm{mg} \text { ZON) or } \\
\text { Water (controls) during } 10 \text { days }\end{array}$ & $\begin{array}{l}\text { Reduced fertility } \\
\text { Reduced ovulation rate } \\
\text { Longer duration of } \\
\text { oestrus }\end{array}$ & $\begin{array}{l}\text { Smith et al., } \\
1986\end{array}$ \\
\hline $\mathrm{ZON}$ & Calf & $\begin{array}{l}250 \mathrm{mg} \text { purified } \mathrm{ZON} / \mathrm{d} \\
\text { during } 3 \text { oestrus cycles }\end{array}$ & $\begin{array}{l}\text { Reduced conception } \\
\text { rates }(87 \text { to } 62 \%)\end{array}$ & $\begin{array}{l}\text { Weaver et al., } \\
\text { 1986a }\end{array}$ \\
\hline $\mathrm{ZON}$ & $\begin{array}{l}\text { Dairy } \\
\text { cow }\end{array}$ & $\begin{array}{l}500 \mathrm{mg} \text { purified } \mathrm{ZON} / \mathrm{d} \\
\text { during } 2 \text { oestrus cycles }\end{array}$ & $\begin{array}{l}\text { No effects on } \\
\text { progesterone } \\
\text { concentration } \\
\text { No alteration of genital } \\
\text { system }\end{array}$ & $\begin{array}{l}\text { Weaver et al., } \\
1986 \text { b }\end{array}$ \\
\hline $\begin{array}{l}\text { ZON } \\
\text { DON }\end{array}$ & $\begin{array}{l}\text { Dairy } \\
\text { cow } \\
\text { Heifers }\end{array}$ & $\begin{array}{l}1.5 \mathrm{mg} \mathrm{ZON} / \mathrm{kg} \text { feed and } 1.0 \\
\mathrm{mg} \text { DON} / \mathrm{kg} \text { feed }\end{array}$ & $\begin{array}{l}\text { False oestrus of } 2 \text { to } 5 \mathrm{~d} \\
\text { duration } \\
\text { Idiopathic vaginitis } \\
\text { Mammary development } \\
\text { occurred in the } \\
\text { prepubertal heifers }\end{array}$ & $\begin{array}{l}\text { Coppock et al., } \\
1990\end{array}$ \\
\hline \multirow[t]{2}{*}{$\mathrm{ZON}$} & Ewe & $\begin{array}{l}0,1.5,3,6,12 \text { and } 24 \mathrm{mg} \\
\text { ZON/day for } 10 \text { days } \\
\text { starting on day } 7 \text { of the } \\
\text { oestrus cycle before mating }\end{array}$ & $\begin{array}{l}\text { Decline in ovulation rate } \\
\text { Decreased cycle length } \\
\text { Increased oestrus duration } \\
\text { Reduced incidence of } \\
\text { ovulation and fertilization } \\
\text { at doses of } 12 \text { and } 24 \mathrm{mg} \\
\text { ZON/d }\end{array}$ & $\begin{array}{l}\text { Smith et al., } \\
1990\end{array}$ \\
\hline & & $\begin{array}{l}0,1.5,3,6,12 \text { and } 24 \mathrm{mg} \\
\text { ZON/day for } 10 \text { days } \\
\text { starting } 5 \text { days after mating to } \\
\text { entire rams }\end{array}$ & $\begin{array}{l}\text { No effect on pregnancy } \\
\text { rate or embryonic loss }\end{array}$ & \\
\hline ZON & $\begin{array}{l}\text { Dairy } \\
\text { cow }\end{array}$ & approximately $0.1 \mathrm{mg} / \mathrm{kg}$ feed & $\begin{array}{l}\text { Increase in the must } \\
\text { secret } \\
\text { Changes in behaviour }\end{array}$ & Drochner, 1990 \\
\hline $\mathrm{ZON}$ & Ram & $12 \mathrm{mg} \mathrm{ZON/d} \mathrm{during} 8$ weeks & $\begin{array}{l}\text { No effects on semen } \\
\text { production }\end{array}$ & $\begin{array}{l}\text { Milano et al., } \\
1991\end{array}$ \\
\hline $\begin{array}{l}\text { ZON } \\
\text { Zeranol }\end{array}$ & Heifer & $\begin{array}{l}1.25 \mathrm{mg} \mathrm{ZON} / \mathrm{kg} \text { bruised oat } \\
\text { or implants: } \\
2 \text { applications with } 25 \mathrm{mg} \\
\text { zeranol at } 6 \text { weeks intervals }\end{array}$ & $\begin{array}{l}\text { Animals feeding the } \\
\text { contaminated feed } \\
\text { showed a higher mean } \\
\text { daily weight gain } \\
\text { No negative effects } \\
\text { on state of health and } \\
\text { reproduction tract }\end{array}$ & Möser, 2001 \\
\hline
\end{tabular}


TABLE 7 Continued

\begin{tabular}{|c|c|c|c|c|}
\hline Toxin & $\begin{array}{l}\text { Animal } \\
\text { species }\end{array}$ & Experimental description & Symptoms & Literature \\
\hline $\begin{array}{l}\text { DON } \\
\text { T2 }\end{array}$ & Steer & $\begin{array}{l}14.5 \mathrm{mg} \mathrm{DON} / \mathrm{kg} \text { diet } \\
4.5 \mathrm{mg} \mathrm{T} 2 / \mathrm{kg} \mathrm{diet}\end{array}$ & Diarrhoea & $\begin{array}{l}\text { Schuh and } \\
\text { Baumgartner, } \\
1988\end{array}$ \\
\hline $\begin{array}{l}\text { DON } \\
\text { ZON }\end{array}$ & Dairy cow & $\begin{array}{l}12.4 \mathrm{mg} \text { DON} / \mathrm{d} \text { and } 0.94 \mathrm{mg} \\
\mathrm{ZON} / \mathrm{d} \text { or } \\
14.1 \mathrm{mg} \text { DON} / \mathrm{d} \text { and } 0.67 \mathrm{mg} \\
\mathrm{ZON} / \mathrm{d} \text { or } \\
14.3 \mathrm{mg} \text { DON} / \mathrm{d} \text { and } 0.68 \\
\mathrm{mg} \mathrm{ZON} / \mathrm{d}+\text { adsorbents } \\
\text { "Mycofix Plus" }\end{array}$ & $\begin{array}{l}\text { No significant } \\
\text { differences in milk } \\
\text { performance and milk } \\
\text { ingredients } \\
\text { Increased activities of } \\
\text { serum enzymes ASAT } \\
\text { and GLDH by all } 3 \\
\text { groups }\end{array}$ & $\begin{array}{l}\text { Hochsteiner et } \\
\text { al., } 2000\end{array}$ \\
\hline $\begin{array}{l}\text { DON } \\
\text { ZON }\end{array}$ & $\begin{array}{l}\text { Growing } \\
\text { bull }\end{array}$ & $\begin{array}{l}2.2 \mathrm{mg} \text { DON and } 0.1 \mathrm{mg} \\
\mathrm{ZON} / \mathrm{kg} \text { complete ration } \\
\text { with or without adsorbents } \\
\text { Mycofix }{ }^{\circledR} \text { Plus (Biomin } \\
\text { GmbH, Herzogenburg, } \\
\text { Austria) }\end{array}$ & $\begin{array}{l}\text { Reduced dressing } \\
\text { percentages } \\
\text { Increased weight of the } \\
\text { emptied gastrointestinal } \\
\text { tract } \\
\text { Reduced weight of the } \\
\text { testicles } \\
\text { Slightly decreased } \\
\text { cholesterol levels in } \\
\text { serum }\end{array}$ & $\begin{array}{l}\text { Dänicke et al., } \\
\text { 2002a }\end{array}$ \\
\hline $\begin{array}{l}\text { DON } \\
\text { ZON }\end{array}$ & Wether & $\begin{array}{l}4.6 \mathrm{mg} \text { DON and } 0.34 \mathrm{mg} \\
\text { ZON/kg complete ration } \\
\text { with or without adsorbens } \\
\text { Mycofix }{ }^{\circledR} \text { Plus (Biomin } \\
\text { GmbH, Herzogenburg, } \\
\text { Austria) }\end{array}$ & $\begin{array}{l}\text { No significant } \\
\text { differences in volatile } \\
\text { fatty acids and ammonia } \\
\text { in rumen fluid } \\
\text { Detoxifying agent exert } \\
\text { a rumen pH-buffering } \\
\text { effect }\end{array}$ & $\begin{array}{l}\text { Dänicke et al., } \\
\text { 2002b }\end{array}$ \\
\hline $\begin{array}{l}\text { DON } \\
\text { ZON }\end{array}$ & Dairy cow & $\begin{array}{l}8.05 \mathrm{mg} \mathrm{DON} / \mathrm{kg} \text { and } 0.26 \\
\mathrm{mg} \mathrm{ZON} / \mathrm{kg} \text { wheat }(35 \mathrm{~d}) \\
7.15 \mathrm{mg} \text { DON} / \mathrm{kg} \text { and } 0.1 \mathrm{mg} \\
\mathrm{ZON} / \mathrm{kg} \text { wheat }(35 \mathrm{~d})\end{array}$ & $\begin{array}{l}\text { Higher ammonium } \\
\text { concentration in the } \\
\text { rumen fluid } \\
\text { Reduced crude protein } \\
\text { flow, flow of microbial } \\
\text { protein and of utilizable } \\
\text { crude protein at the } \\
\text { duodenum }\end{array}$ & $\begin{array}{l}\text { Dänicke et al., } \\
2005\end{array}$ \\
\hline $\begin{array}{l}\text { DON } \\
\text { ZON }\end{array}$ & Dairy cow & $\begin{array}{l}5.2 \mathrm{mg} \text { DON and } 60 \mu \mathrm{g} \\
\mathrm{ZON} / \mathrm{kg} \text { concentrate }\end{array}$ & $\begin{array}{l}\text { No significant } \\
\text { differences in } \mathrm{pH} \text {-value } \\
\text { in rumen fluid } \\
\text { Increase amount of } \\
\text { crude protein degraded } \\
\text { at the duodenum }\end{array}$ & $\begin{array}{l}\text { Seeling et al., } \\
2005\end{array}$ \\
\hline
\end{tabular}

$\overline{\mathrm{GLDH}}=$ glutamate dehydrogenase, ASAT $=$ aspartate aminotransferase 
Weaver et al. (1986a) orally administrated a daily dose of $250 \mathrm{mg}$ purified ZON to heifers during one oestrus cycle and for 45 days after they conceived. While the conception rate of the control heifers amounted to $87 \%$, only $62 \%$ were observed for the treated group. However, following a daily oral exposure of 500 mg purified ZON during a period of two oestrous cycles, no adverse effects of the progesterone concentration and no alterations of the genital system were found (Weaver et al., 1986b).

Also, the reproductive performance of ewes after administration of ZON was determined (Smith et al., 1986). The exposure of ewes dosed with $25 \mathrm{mg} Z O N$ per day for 10 days before mating resulted in prolonged oestrous behaviour, reduced ovulation rate and reduced fertility. Accordingly, daily administration of 1.5, 3, 6, 12 and $24 \mathrm{mg}$ ZON to 33 ewes premating caused a linear decline in the ovulation rate, a decreased cycle length and an increased duration of oestrus (Smith et al., 1990). Reductions in the incidence of ovulation and in fertilization were observed only at daily doses of 12 and $24 \mathrm{mg} Z \mathrm{ZON}$. There were no effects of ZON treatment $(1.5,3,6,12$ and $24 \mathrm{mg} / \mathrm{d})$ on pregnancy rate or embryonic loss of the ewes when $\mathrm{ZON}$ was administered post mating. Apparently, ewes are only influenced by ZON when dosed prior to mating. In contrast, adult male sheep seemed to be unaffected by ZON administration. In a study by Milano et al. (1991) rams were fed a diet of naturally contaminated maize containing $12 \mathrm{mg} \mathrm{ZON} / \mathrm{kg}$ (equivalent to $12 \mathrm{mg}$ $\mathrm{ZON} / \mathrm{d}$ ) for eight weeks. No significant effects of sperm production, spermatozoal mass motility and spermatozoal morphology were observed.

\section{FACTORS OTHER THAN DOSAGE AND DURATION OF TOXIN EXPOSITION WHICH COULD INFLUENCE THE VARIABILITY OF TOXIN EFFECTS IN RUMINANTS AND OF CARRY OVER}

\section{Species and race}

With regard to the mycotoxins DON and $\mathrm{ZON}$ it has been well documented that wide differences exist in sensitivities between several animal species which are also reflected in the orientation values for critical concentrations of DON and ZON in feedstuffs (BML, 2000; Table 8). Monogastric animals, especially pigs, show the greatest sensitivity, while chickens and ruminants appear to have a higher tolerance. The higher insensitivity of ruminants to the toxins is attributed to the metabolization of these substances by microbes in the rumen. Several in vitro studies have demonstrated that DON undergoes rapid biotransformation to de-epoxy DON by rumen microflora before being absorbed. Results of Kiessling et al. (1984), who were unable to show any degradation of DON by rumen 
TABLE 8

Orientation values for critical concentrations of deoxynivalenol and zearalenone in the diets for pigs, ruminants and gallinaceous poultry, $\mathrm{mg} / \mathrm{kg}$ at $88 \%$ dry matter (BML, 2000)

\begin{tabular}{llcc}
\hline & \multicolumn{1}{c}{ Animal species } & Deoxynivalenol & Zearalenone \\
\hline Pig & Prepubertal female breeding pigs & 1.0 & 0.05 \\
& Fattening pigs and breeding sows & 1.0 & 0.25 \\
Poultry & Laying hens and fattening hens & 5.0 & $-{ }^{1}$ \\
& & & \\
Cattle & Calves (preruminating) & 2.0 & 0.25 \\
& Female rearing cattle/dairy cows & 5.0 & 0.5 \\
& Fattening cattle & 5.0 & -1 \\
\hline
\end{tabular}

${ }^{1}$ no orientation values are required at the present time

ingesta in vitro, are in contradiction with the findings of other authors. King et al. (1984) demonstrated that DON was almost completely metabolized to a single deepoxidation product within $24 \mathrm{~h}$ using bovine rumen fluid, while Ivie (1976) showed an epoxide to olefin transformation by rumen digesta. In a study by Swanson et al. (1987) incubation periods longer than $48 \mathrm{~h}$ are required for complete biotransformation of DON to de-epoxy DON. Also He et al. (1992) detected the de-epoxy metabolite of DON after anaerobe incubation of rumen fluid. Although the protozoa fraction seems to be more effective in toxin degradation than the bacterial fraction, the rumen bacteria appear to have increased resistance to the toxic effects of trichothecenes (Westlake et al., 1989). Whitlow and Hagler (1999) noted that, although not compared directly up to now, beef cattle and sheep appear to be less sensitive to DON than dairy cattle. The authors supposed that differences could be related to level of production stress, since mid-lactation, low-producing dairy cattle also appear to be more tolerant to DON than high-producing dairy cattle in early lactation. Early lactating, high producing cows experience greater stress, lower immunity, marginal nutrient deficiencies and a faster rumen turnover and it is possible that these factors are responsible for the higher vulnerability.

Also, several in vitro studies with bovine rumen fluid indicate that $\mathrm{ZON}$ was almost completely degraded to $\alpha$ - and $\beta$-ZOL after 3 up to $10 \mathrm{~h}$, whereby the amount of degradation was dependent on the concentration of ZON (Kallela and Vasenius, 1982; Kiessling et al., 1984; Miettinen and Oranen, 1994). $\beta$-ZOL was particularly metabolized to $\alpha$-ZOL and the parent toxin, while $\alpha$-ZOL was regenerated only to a minor extent to ZON (Lerch, 1990). Also, in vitro investigations of Valenta and Vemmer (1996) confirmed the formation of ZON to $\alpha$ - and $\beta$-ZOL at the ratio $2: 1$ and $3: 1$, but approximately $50 \%$ of the added $\mathrm{ZON}$ remained after $24 \mathrm{~h}$. Moreover, ZON as well as the isomers zearalenol could be detected after incubation of $\alpha$ - and $\beta$-ZOL. The authors assumed that 
a redox equilibrium between $\mathrm{ZON}$ and the two metabolites exists and therefore a complete degradation of ZON to $\alpha$ - and $\beta$-ZOL in the rumen seems to be questionable. Moreover, Kallela and Vasenius (1982) supposed that the higher tolerance of ruminants to $\mathrm{ZON}$ can be attributed to the ruminal metabolization of the toxin. However, the transformation of ZON to $\alpha$ - and $\beta-Z O L$ is not regarded as detoxification because both products are still oestrogenic (Hagler et al., 1980; see chapter Zearalenone). Therefore, other factors may have caused the lesser toxicity of ZON to ruminants. Possibly, differences in response to $\mathrm{ZON}$ are related to differences in the affinity of $\mathrm{ZON}$ and its metabolites to the oestrogen receptor since Fitzpatrick et al. (1989) showed that considerable differences in the affinity of $\alpha$-ZOL to the oestrogen receptor exist between pigs, rats and chickens.

Age

Bauer (2002) suggested that preruminating calves are similarly sensitive to mycotoxins as monogastric animals. As mentioned above, ruminants are generally less susceptible to Fusarium toxins as compared to monogastric animals which is related to the metabolization of these substances by microorganisms in the rumen. However, with regard to the rumen development, differences should be considered between fattening cattle, dairy cows, ruminant and preruminant young calves. In a study with calves and ochratoxin A, a mycotoxin produced by the fungal genera Aspergillus and Penicillium, Sreemannarayana et al. (1988) suggested that age as a determinant in the development of a functional rumen greatly modifies the susceptibility of young calves to the toxic action of the toxin. In vitro studies with rumen fluid collected from cows and sheep showed that ochratoxin A is hydrolysed enzymatically by microflora in the rumen to the non-toxic dihydroxyisocoumarin (ochratoxin $\alpha$ ) by splitting-off the amino acid phenylalanine which is responsible for toxicity (Kiessling et al., 1984; Xiao et al., 1991). Sreemannarayana et al. (1988) administered an oral dose of ochratoxin A of $4.0 \mathrm{mg} / \mathrm{kg} \mathrm{BW}$ to two preruminant calves. Both calves died within $24 \mathrm{~h}$. At a lower oral dose of $1 \mathrm{mg} / \mathrm{kg} \mathrm{BW}$ administered to two preruminant calves, one calf died $12 \mathrm{~h}$ after dosing, the second survived for 10 days. In contrast, all four calves with functional rumen receiving orally $2.0 \mathrm{mg}$ ochratoxin $\mathrm{A} / \mathrm{kg}$ body weight survived without overt ill effects. These results confirm that the capacity of detoxification also depends on development of the rumen which becomes functional at 4 to 6 month (Ribelin, 1978). This can explain the higher tolerance of ruminant calves to harmful or toxic substances such as DON in comparison to preruminant calves.

Age and sex dependent differences in the susceptibility to ZON are also known for pigs. Especially prepubertal female pigs react most sensitively which is attributable to their available oestrogen receptor affinity as well as the lack of 
competition of own oestrogens, while sows are more tolerant due to their high cyclic oestrogen levels (Drochner, 2002). Likewise, female ruminants show increased oestrogen concentrations in the blood with progressing pregnancy. Therefore, it is possible that the natural differences in the oestrogen level are also responsible for varying sensibilities of female calves, heifers, and low- and highproducing dairy cows to $\mathrm{ZON}$.

\section{Ration composition}

While in vitro experiments of Valenta and Vemmer (1996) did not show an obvious influence of the feeding regime on the metabolization of ZON to $\alpha-Z O L$ and $\beta$-ZOL, Kallela and Vasenius (1982) indicated that the quality of rumen fluid had a significant effect on the ratio of the toxin metabolization. This assumption is consistent with results of several in vitro studies with ochratoxin A (Müller et al., 1998, 2001; Özpinar et al., 1999). Müller et al. (2001) added pure ochratoxin A to rumen fluid from cows which were fed six diets containing grass, grass silage or hay and two different amounts of concentrate consisting of barley and soyabean meal. The authors observed a disappearance of ochratoxin A accompanied by an appearance of ochratoxin $\alpha$ in the rumen fluid by replacing grass silage or hay by fresh grass and by increasing the level of concentrate in the total diet. They concluded that the decrease of ochratoxin A resulted from an increased number and/or activity of protozoa which are able to hydrolyse the toxin and which are known to increase in total numbers when level of concentrate and thereby amount of metabolizable energy is increased (Eadie et al., 1970; Abe et al., 1973). Accordingly, Özpinar et al. (1999) found an increased velocity of degradation of ochratoxin A in ruminal fluid when the concentration of starch in the diet increased, while an influence of the $\mathrm{pH}$-value was not apparent. However, Xiao et al. (1991) observed a five-fold lower rate of ochratoxin A metabolization to ochratoxin $\alpha$ by using ruminal fluid with a lower $\mathrm{pH}$. Accordingly, He et al. (1992) reported that the response of chicken large intestine contents dosed with DON was also $\mathrm{pH}$-dependent. The biotransformation of DON was inhibited when $\mathrm{pH}$ of the media was decreased. A lower ruminal $\mathrm{pH}$ is well known to be a result of a higher concentrate level in the feed, and especially fattening ruminants and highyielding dairy cows are fed diets containing higher amounts of concentrate and lower amounts of roughage. Furthermore, in consideration of the small amount of crude fibre in such diets, Lew (1999) supposed a not completely functional rumen with a lower detoxification capacity. Therefore it is possible that high performing ruminants, which are fed diets containing high levels of concentrate, can already show clinical effects when DON containing diets with concentrations as low as $0.5 \mathrm{mg} / \mathrm{kg}$ are fed over longer periods of time (Schuh, 1996). 
It can be concluded that the diet of ruminant animals, which can affect rumen microbial composition and numbers (Mackie et al., 1978; Leedle et al., 1982), may be an important determinant in the relative toxin resistance of these animals (Westlake et al., 1989).

\section{Passage rate}

The essential digestibility processes of ruminants are dependent on microbial fermentation. As explained in chapter Species and race, the mycotoxins DON and $\mathrm{ZON}$ are also metabolized by rumen microorganisms. Therefore it is possible that factors affecting the digestibility of dietary components could also influence the metabolization of the toxins.

Faichney (1980) suggested that the extent of digestibility of dietary components in the rumen is a function of rate of digestion and rate of passage. The latter, in turn, is also affected by the level of feed intake. A decreased level of feed intake is associated with a decreased rate of passage (Evans, 1981; Uden, 1984), whereas a high passage rate is related to a lower ruminal retention time. Ruminal retention time of dietary ingredients is quite variable and varies not only from one diet to another, but also between animals and species (Tamminga, 1979). Rumen retention times are higher in beef animals than in dairy cows and they also differ between dairy cattle because level of feed intake varies up to five-fold or more during the course of lactation (Sniffen and Robinson, 1987; Tarr, 1996). It is possible that the retention time of the feed in the rumen, as result of the feed intake, could affect the ruminal metabolization of the toxins. A rapid passage rate may limit the metabolization of the mycotoxins in the rumen. Therefore, it is possible that due to a passage rate dependent metabolization, the toxin and metabolite profile could be altered which could modify the toxicity. However, regarding the Fusarium toxins DON and ZON, no data are available of studies which consider feeding situations resulting in different ruminal passage rates.

\section{CONCLUSIONS}

This review has shown that it is difficult to draw conclusions for the practical feeding of DON and ZON contaminated feedstuffs to ruminants due to the limited and inconsistent literature data on the effects of the toxins on health and performance of these animals. Moreover, very little information is available about factors others than time of exposure and dose of the toxins, which could influence the variability not only of toxin effects but also of carry over of these toxins and/or their metabolites into milk and other foodstuffs of ruminant origin. 
In most instances merely case or field reports were given. Experiments under controlled conditions were only performed with rather low numbers of animals during limited periods of time using either purified toxins or naturally contaminated feed, which can contain a natural cocktail of several mycotoxins. Then it is often not possible to distinguish whether mycotoxicosis results from the exposure of one mycotoxin or of a group of other not detected/unknown toxins/ substances, the interactions between the different toxins/substances or maybe from fungus related modifications of the feed.

Therefore, accurately defined studies with ruminants, especially with lactating dairy cows, feed DON and ZON in practically relevant concentrations during a longer period are required. In addition, future research should consider genetic and physiological factors such as age, hormone status, nutrition and ruminal microflora which also seem to influence the variability of the effects of DON and $\mathrm{ZON}$ on the health of ruminants and on carry over.

\section{REFERENCES}

Abe M., Shibui H., Iriki T., Kumeno F., 1973. Relation between diet and protozoal population in the rumen. Brit. J. Nutr. 29, 197-202

Anderson V.L., Boland E.W., Casper H.H., 1995. The effects of vomitoxin (DON) from scab infested barley fed to gestating and lactating heifers. Beef Production Field Day. Carrington Research Extention Center. Livestock Unit. NDSU Agr. Expt. Sta. 18, 10-12

Bauer J., 2000. Mykotoxine in Futtermitteln: Einfluss auf Gesundheit und Leistung. In: Handbuch der tierischen Veredlung. 25. Auflage. Kammlage-Verlag, Osnabrück, pp. 169-192

Bauer J., 2002. Mycotoxins in feedstuffs for ruminants: biochemical effects and clinical relevance. In: M. Kaske, H. Scholz, M. Höltershinken (Editors). Recent Developments and Perspectives in Bovine Medicine, XXII World Buiatrics Congress, Hannover. Hildesheimer Druck- und Verlags-GmbH Hildesheim, pp. 168-180

Betina V., 1989. Mycotoxins: Chemical, Biological and Environmental Aspects. Bioactive Molecules. Vol. 9. Amsterdam/New York, Elsevier

Biehl M.L., Prelusky D.B., Koritz G.D., Hartin K.E., Buck W.B., Trenholm H.L., 1993. Biliary excretion and enterohepatic cycling of zearalenone in immature pigs. Toxicol Appl. Pharmacol. 12, 152-159

Bloomquist C., Davidson J.N., Pearson E.G., 1982. Zearalenone toxicosis in prepubertal dairy heifers. J. Amer. Vet. Med. Assn. 180, 164-165

BML, The German Federal Ministry of Nutrition, Agriculture and Forestry, 2000. Orientation values for critical concentrations of deoxynivalenol and zearalenone in diets for pigs, ruminants and gallinaceous poultry. VDM 27/00, 2-3

Boland E.W., Anderson V.L., Casper H.H., Berg P.T., Dhuyvetter D.V., 1994. The effects of increasing vomitoxin (DON) levels from scab infested barley fed to feedlot steers. Beef Production Field Day. Carrington Research Extention Center. Livestock Unit. NDSU Agr. Expt. Sta. 17, 34-38

Bottalico A., 1998. Fusarium diseases of cereals: species complex and related mycotoxin profiles, in Europe. J. Plant Pathology 80, 85-103

Bottalico A., Perrone G., 2002. Toxigenic Fusarium species and mycotoxins associated with head blight in small-grain cereals in Europe. Eur. J. Plant Pathol. 108, 611-624 
Charmley E., Trenholm H.L., Thompson B.K., Vudathala D., Nicholson J.W.G., Prelusky D.B., Charmley L.L., 1993. Influence of level of deoxynivalenol in the diet of dairy cows on feed intake, milk production, and its composition. J. Dairy Sci. 76, 3580-3587

Cappock R.W., Mostrom M.S., Sparling C.G., Jacobsen B., Ross S.C., 1990. Apparent zearalenone intoxication in a dairy herd from feeding spoiled acid-treated corn. Vet. Hum. Toxicol. 32, 246-248

Cote L.M., Dahlem A.M., Yoshizawa T., Swanson S.P., Buck W.B., 1986. Excretion of deoxynivalenol and its metabolites in milk, urine, and feces of lactating dairy cows. J. Dairy Sci. 69, 2416-2423

Dänicke S., 2002. Effects of Fusarium toxin contaminated wheat grain and of a detoxifying agent on rumen physiological parameters and in sacco dry matter degradation of wheat straw and lucerne hay in wethers. J. Anim. Feed Sci. 11, 437-451

Dänicke S., Gädeken D., Ueberschär K.-H., Scholz H., 2002. Effects of Fusarium toxin contaminated wheat and of a detoxifying agent on performance of growing bulls, on nutrient digestibility in wethers and on the carry over of zearalenone. Arch. Anim. Nutr. 56, 245-261

Dänicke S., Matthäus K., Lebzien P., Valenta H., Ueberschär K.-H., Flachowsky G., 2005. On the effects of Fusarium toxins on the fermentation and nutrient utilization in rumen of dairy cows. J. Anim. Physiol. Anim. Nutr. (in press)

Dänicke S., Valenta H., Ueberschär K.H., 2000. Risikoabschätzung und Vermeidungsstrategien bei der Fütterung. In: S. Dänicke, E. Oldenburg (Editors). Risikofaktoren für die Fusariumtoxinbildung in Futtermitteln und Vermeidungsstrategien bei der Futtermittelerzeugung und Fütterung. Landbauforsch. Völkenrode, Sonderheft 216, 5-34

DeHaan K.A., Stock R.A., Brink D.R., Klopfenstein T.J., 1983. The effect of deoxynivalenol contaminated wheat on performance of cattle and sheep. J. Anim. Sci. 57, 427

DiCostanzo A., Johnston L., Felice L., Murphy M., 1995. Effects of molds on nutrient content of feeds reviewed. Feedstuffs $67(16,17), 52,54$

Döll S., Valenta H., Kirchheim U., Flachowsky G., 2002. Fusarium mycotoxins in conventionally and organically grown grain from Thuringia/Germany. Landbauforsch. Völkenrode 52, 91-96

Drochner W., 1990. Aktuelle Aspekte zur Wirkung von Phytohormonen, Mykotoxinen und ausgewählten schädlichen Pflanzeninhaltsstoffen auf die Fruchtbarkeit beim weiblichen Rind. Übersichten Tierernähr. 18, 177-196

Drochner W., 2002. Neues zur Mykotoxinen und deren Problematik in der Fütterung. Themen zur Tierernährung Zusammenfassung der Vorträge des Fachgespräches über aktuelle Fragen zur Tierernährung. Themen zur Tierernährung 2002/2003. Zusammenfassung der Vorträge des Fachgespräches über aktuelle Fragen zur Tierernährung, Agrarpolitik und Veredlungswirtschaft am 28.11.2002 in Neuenkirchen-Vörden und am 30.01.2003 in Hodenhagen

Drochner W., Heckötter E., Scholz H., 1984. Aktuelle Ergebnisse aus der tierärztlichen Fütterungsberatung. 4. Mitteilung: Die Zusammensetzung von Grünfutter und Silagen für Wiederkäuer; Untersuchungen von Einzelfuttermitteln für Wiederkäuer in Problembeständen (ein Erfahrungsbericht). Deut. Tierärztl. Wochenschr. 91, 45-84

Dupchak K., 1998. Feeding Fusarium contaminated grain to livestock. ushttp:/www.gov.mb.ca /agriculture/livestock/bza00s01.html/us from 4th January 2002

D’Mello J.P.F., Placinta C.M., MacDonald A.M.C., 1999. Fusarium mycotoxins: a review of global implications for animal health, welfare and productivity. Anim. Feed Sci. Tech. 80, 183-205

Eadie J.M., Hyldgaard-Jensen J., Mann S.O., Reid R.S., Whitelaw F.G., 1970. Observations on the microbiology and biochemistry of the rumen in cattle given different quantities of a pelleted barley ration. Brit. J. Nutr. 24, 157-177

Ehrlich K.C., Diagle K.W., 1987. Protein synthesis inhibition by 8-oxo-12,13-epoxytrichothecenes. Biochim. Biophys. Acta. 923, 206-213 
Ellend N., Galsterer G., Binder E.M., 1998. Mykotoxine in österreichischem Mais - Eine Zweijahresübersicht. Mycotoxin Res. 14, 126-130

Engels R., Krämer J., 1996. Incidence of Fusaria and occurrence of selected Fusarium mycotoxins on Lolium spp. in Germany. Mycotoxin Res. 12, 31-40

Erasmuson A.F., Scahill B.G., West D.M., 1994. Natural zeranol ( $\alpha$-zearalanol) in the urine of pasture-fed animals. J. Agr. Food Chem. 42, 2721-2725

Eriksen G.S., Alexander J., 1998. Fusarium toxins in cereals - a risk assessment. Nordic Council of Ministers, Copenhagen TemaNord, 502, 45-58

European Union. Council directive of 7 March 1988 prohibiting the use in livestock farming of certain substances having a hormonal action (88/146/EEC). Off. J. Eur. Communities 1988, L $70 / 16$

Evans E., 1981. An evaluation of the relationship between dietary parameters and rumen solid turnover rate. Can. J. Anim. Sci. 61, 97-103

Faichney G.J., 1980. Measurement in sheep of the quantity and composition of rumen digesta and of the fractional outflow rates of digesta constituents. Aust. J. Agr. Res. 31, 1129-1137

Feinberg B., McLaughlin C.S., 1989. Biochemical mechanism of action of trichothecene mycotoxins. In: V.R. Beasley (Editor). Trichothecene Mycotoxicosis: Pathophysiological Effects. Vol. I. CRC Press, Inc. Boca Raton, Florida, pp. 27-35

Fitzpatrick D.W., Picken C.A., Murphy L.C., Buhr M.M., 1989. Measurement of the relative binding affinity of zearalenone, $\alpha$-zearalenol and $\beta$-zearalenol for uterine and oviduct estrogen receptors in swine, rats and chickens: an indicator of estrogenic potencies. Comp. Biochem. Physiol. 94, 691-694

Goll M., Valenta H., Oldenburg E., 1995. Übergang von Zearalenon in die Milch von Kühen nach Langzeitfütterung. Landbauforsch. Völkenrode, Sonderheft 157, 131-134

Hagler W.M., Danko G., Horvath L., Palyusik M., Mirocha C.J., 1980. Transmission of zearalenone and its metabolite into ruminant milk. Acta Vet. Acad. Sci. Hung. 28, 209-216

Harvey R.B., Kubena L.F., Corrier D.E., Witzel D.A., Phillips T.D., Heidelbaugh N.D., 1986. Effects of deoxynivalenol in a wheat ration fed to growing lambs. Amer. J. Vet. Res. 47, 1630-1632

He P., Young L.G., Forsberg C., 1992. Microbial transformation of deoxynivalenol (vomitoxin). Appl. Environ. Microbiol. 58, 3857-3863

Hochsteiner W., Schuh M., Luger K., Baumgartner W., 2000. Einfluß von mykotoxinkontaminiertem Futter auf Leistungsparameter beim Milchrind. Berl. Münch. Tierärztl. Wochenschr. 113, 14-21

Höltershinken M., Maiworm K., Scholz H., 1996. Mykotoxikosen beim Rind - Probleme auch in Norddeutschland? Coll. Vet. 26, 9-14

IARC, 1993. Toxins derived from Fusarium graminearum, F. culmorum and F. crookwellense: zearalenone, deoxynivalenol, nivalenol and fusarenone X. IARC Monogr. Eval. Carcinog. Risks Hum. 56, 397-444

Ingalls J.R., 1996. Influence of deoxynivalenol on feed consumption by dairy cows. Anim. Feed Sci. Tech. 60, 297-300

Ivie C.W., 1976. Epoxide to olefin: a novel biotransformation in the rumen. Science 19, 959-961

Kallela K., Ettala E., 1984. The estrogenic Fusarium toxin (zearalenon) in hay as a cause of early abortions in the cow. Nord. Vet. Med. 36, 305-309

Kallela K., Vasenius L., 1982. The effect of rumen fluid on the content of zearalenone in animal fodder. Nord. Vet. Med. 31, 336-339

Kang Z., Buchenauer H., 2000. Ultrastructural and cytochemical studies on cellulose, xylan and pectin degradation in wheat spikes infected by Fusarium culmorum. J. Phytopathol. 148, 263-275

Kennedy D.G., Hewitt S.A., McEvoy J.D.G., Currie J.W., Cannavan A., Blanchflower W.J., Elliot C.T., 1998. Zeranol is formed from fusarium spp. toxins in cattle in vivo. Food Addit. Contam. $15,393-400$ 
Kennedy D.G., McEvoy J.D.G., Blanchflower W.J., Hewitt S.A., Cannavan A., McCaughey W. J., Elliot C.T., 1995. Possible naturally occurring zeranol in bovine bile in Northern Ireland. Zbl. Vet. Med. B 42, 509-512

Kiessling K.-H., Petterson H., 1978. Metabolism of zearalenone in rat liver. Acta Pharmacol. Toxicol. 43, 285-290

Kiessling K.-H., Petterson H., Sandholm K., Olsen M., 1984. Metabolism of aflatoxin, ochratoxin, zearalenon, and three trichothecenes by intact rumen fluid, rumen protozoa and rumen bacteria. Appl. Environ. Microbiol. 47, 1070-1073

King R.R., McQueen R.E., Levesque D., Greenhalgh R., 1984. Transformation of deoxynivalenol (vomitoxin) by rumen microorganisms. J. Agr. Food Chem. 32, 1181-1183

Kirchheim U., Hartung H., Herold L., Meixner B., 2002. Monitoring of Fusarium toxins in cereals and feedstuffs from Thuringia (1998-2001). Mycotoxin Res. 18, 28-31

Kirchheim U., Hartung H., Herold L., Meixner B., 2003. Fusarientoxine in Thüringer Getreide, Getreiderzeugnissen sowie Futtermitteln - Ergebnisse des Jahres 2002. Abstr. 25. MykotoxinWorkshop Giessen, 50

Kleinova M., Zöllner P., Kahlbacher H., Hochsteiner W., Lindner W., 2002. Metabolic profiles of the mycotoxin zearalenone and of the growth promoter zeranol in urine, liver, and muscle of heifers. J. Agr. Food Chem. 50, 4769-4776

Kuhlmann I., Valenta H., Goll M., Oldenburg E., Flachowsky G., 1999. Untersuchungen zum Schimmelpizbesatz und Mykotoxingehalt in Getreide aus Thüringen und Sachsen-Anhalt von 1996. Mycotoxin Res. 15, 31-35

Kuiper-Goodman T., Scott P.M., Watanabe H., 1987. Risk Assessment of the mycotoxin zearalenone. Regul. Toxicol. Pharmacol. 7, 253-306

Langseth W., Ghebremeskel M., Kosiak B., Kolsaker P., Miller D., 2001. Production of culmorin compounds and other secondary metabolites by Fusarium culmorum and Fusarium graminearum strains isolated from Norwegian cereals. Mycopathology 152, 23-24

Leedle J.A.Z., Bryant M.P., Hespell R.B., 1982. Diurnal variations in bacterial numbers and fluid parameters in ruminal contents of animals fed low- or high-forage diets. Appl. Environ. Microbiol. 44, 402-412

Lepom P., 1988. Untersuchung zur Bildung und zum Nachweis von Fusarium-Toxinen. Dissertation, Berlin, Akademie für Landwirtschaftswissenschaft

Lepom P., Weise G., 1989. Vorkommen von Fusarium-Arten und ihren Mykotoxinen auf Silomais.

4. Mitteilung: Untersuchungen zum Vorkommen von Zearalenon in der Anschnittzone eines Horizontalsilos. Arch. Anim. Nutr. 39, 369-373

Lerch C., 1990. Metabolismus von Ochratoxin A und Zearalenon in Pansenflüssigkeit von Milchkühen in vitro. Dissertation, Landwirtschaftliche Fakultät Stuttgart-Hohenheim

Lew H., 1995. Mykotoxinbelastung von Getreide und Konsequenzen für seine Verarbeitung. Getreide, Mehl, Brot 49, 16-19

Lew H., 1999. Empfohlenes Richtwerteschema für Desoxynivalenol (Vomitoxin) und Zearalenon im Futter. Förderdienst 47, 157

Lew H., Adler A., Brodacz W., Edinger W., 1997. Zum Vorkommen von Nivalenol in Getreide und Mais. Mycotoxin Res. 19, 6-9

LUFA Nord-West, 2002. Landwirtschaftsblatt Weser-Ems 149, Ausg. 51/52 vom 20.09, 30-32

Maiworm K., Höltershinken M., Scholz H., 1995. Auswirkungen verdorbener Maissilage auf Fermentationsvorgänge im Pansensaft des Rindes (in vitro). Tierärztl. Umsch. 50, 283-290

Marx H., Gedek B., Kollarczik B., 1995. Vergleichende Untersuchungen zum mykotoxikologischen Status von ökologisch und konventionell angebautem Getreide. Z. Lebensm. Unters. Forsch. 201, 83-86 
Matthäus K., Dänicke S., Vahjen W., Simon O., Wang J., Valenta H., Meyer K., Strumpf A., Zieseniß H., Flachowsky G., 2004. Progression of mycotoxin and nutrient concentrations in wheat after inoculation with Fusarium culmorum. Arch. Anim. Nutr. 58, 19-35

McLaughlin C.S., Vaughn M.H., Campbell J.M., Wei C.M., Stafford M.E., 1977. Inhibition of protein synthesis by trichothecenes. In: J.V. Rodricks, C.W. Hesseltine, M.A. Mehlman (Editors). Mycotoxins in Human and Animal Health. Park Forest South. Pathotoxin Publishers, pp. 263-273

Miettinen H., Oranen H., 1994. Metabolism of zearalenone by rumen fluid. Proc. Soc. Nutr. Physiol. 3,202

Milano G.D., Odriozola E., Lopez T.A., 1991. Lack of effect of a diet containing zearalenone on spermatogenesis in rams. Vet. Rec. 129, 33-35

Miles C.O., Erasmuson A.F., Wilkins A.I., Towers N.R., Smith B.L., Garthwaite I., Scahill B.G., Hansen R.P., 1996. Bovine metabolism of zearalenone to $\alpha$-zearalanol (zeranol). J. Agr. Food Chem. 44, 3244-3250

Mirocha C.J., Christensen C.M., 1974. Fungus metabolites toxic to animals. Annu. Rev. Phytopathol. $12,303-330$

Mirocha C.J., Harrison J., Nichols A.A., McCintock M., 1968. Detection of a fungal estrogen (f-2) in hay associated with infertility in dairy cattle. Appl. Microbiol. 16, 797-798

Mirocha C.J., Pathre S.V., Robison T.S., 1981. Comparative metabolism of zearalenone and transmission into bovine milk. Food Cosmet. Toxicol. 19, 25-30

Möser S., 2001. Einfluss von Zearalenon und Zearanol bei Kalbinnen. Dissertation, Veterinärmedizinische Universität Wien

Müller H.M., Lerch C., Müller K., Eggert W., 1998. Kinetic profiles of ochratoxin A and ochratoxin a during in vitro incubation in buffered forestomach and abomasal contents from cows. Nat. Toxins $6,251-258$

Müller H.M., Müller K., Steingass H., 2001. Effect of feeding regime on the metabolism of ochratoxin A during the in vitro incubation in buffered rumen fluid from cows. Arch. Anim. Nutr. 54, 265-279

Müller H.M., Reimann J., Schumacher U., Schwadorf K., 1997. Fusarium toxins in wheat harvested during six years in an area of southwest Germany. Nat. Toxins 5, 24-30

Nelson M., Schneider N.R., Doster A.R., Carlson M.P., Klopfenstein T., 1984. Vomitoxin-contaminated wheat - pathology, toxicity in cattle. Nebraska Beef Cattle Report MP-47, pp. 3-12

Noller C.H., Stob M., Tuite J., 1979. Effects of feeding Gibberella zeae-infected corn on feed intake, body weight gain, and milk production of dairy cows. J. Dairy Sci. 62, 1003-1006

Oldenburg E., 1997. Fusarientoxine in Silomais - Abhängigkeit von Sorte und Standort. Jahresbericht 1997 der Bundesforschungsanstalt für Landwirtschaft Braunschweig-Völkenrode (FAL), 29

Oldenburg E., 1999. Fungal secondary metabolites in forages: occurrence, biological effects and prevention. In: Contributions of Grassland and Forage Research to the Development of Systems of Sustainable Land Use. Papers of the International Symposium held in Braunschweig. Landbauforsch. Völkenrode, Sonderheft 206, 91-109

Oldenburg E., Höppner F., 2003. Fusarium mycotoxins in silo maize - occurrence, risk assessment, minimization. Mycotox. Res. 19, 43-46

Oldenburg E., Lepschy J., Valenta H., Weißbach F., 1996. Fusarientoxine in Silomais - Abhängigkeit von Sorte und Standort. Mycotoxin Res. 12, 174-179

Oldenburg E., Valenta H., Sator C., 2000. Risikoabschätzung und Vermeidungsstrategien bei der Futtermittelerzeugung. In: S. Dänicke, E. Oldenburg (Editors). Risikofaktoren für die Fusariumtoxinbildung in Futtermitteln und Vermeidungsstrategien bei der Futtermittelerzeugung und Fütterung. Landbauforsch. Völkenrode, Sonderheft 216, 5-34 
Olsen M., 1989. Metabolism of zearalenone in farm animals. In: J. Chelowski (Editor). Fusarium Mycotoxins, Taxonomy, Pathogenicity. Elsevier, Amsterdam, pp. 167-177

Olsen M., Kiessling K.H., 1983. Species differences in zearalenone-reducing activity in subcellular fractions of liver from female domestic animals. Acta. Pharmacol. Toxicol. 52, 287-291

Özpinar H., Augonyte G., Drochner W., 1999. Inactivation of ochratoxin in ruminal fluid with variation of $\mathrm{pH}$-value and fermentation parameters in an in vitro system. Environ. Toxicol. Pharmacol. 7, 1-9

Pathre S.V., Mirocha C.J., 1976. Zearalenone and related compounds. In: J.V. Rodricks (Editor). Mycotoxins and other Fungal Related Food Problems. Adv. Chem. Ser. 149, 178-227

Prelusky D.B., Hartin K.E., Trenholm H.L., 1990a. Distribution of deoxynivalenol in cerebral spinal fluid following administration to swine and sheep. J. Environ. Sci. Health B 25, 395-413

Prelusky D.B., Scott P.M., Trenholm H.L., Lawrence G.A., 1990b. Minimal transmission of zearalenone to milk of dairy cows. J. Environ. Sci. Health B 25, 87-103

Prelusky D.B., Trenholm H.L., Lawrence G.A., Scott P.M., 1984. Transmission of deoxynivalenol (vomitoxin) to milk following oral administration to dairy cows. J. Environ. Sci. Health B 19, 593-609

Prelusky D.B., Veira D.M., Trenholm H.L., 1985. Plasma pharmacokinetics of the mycotoxin deoxynivalenol following oral and intravenous administration to sheep. J. Environ. Sci. Health B 20, 603-624

Prelusky D.B., Veira D.M., Trenholm H.L., Foster B.C., 1987. Metabolic-fate and elimination in milk, urine and bile of deoxynivalenol following administration to lactating sheep. J. Environ. Sci. Health B 22, 125-148

Prelusky D.B., Veira D.M., Trenholm H.L., Hartin K.E., 1986. Excretion profiles of the mycotoxin deoxynivalenol, following oral and intravenous administration to lactating sheep. Fund. Appl. Toxicol. 6, 356-363

Reutter M., 1999. Zearalenon und Deoxynivalenol in Getreide und Futtermitteln Schleswig-Holsteins: Untersuchungen aus dem Erntejahr 1998. Mycotoxin Res. 15, 5-9

Reutter M., 2002. Mykototoxingehalte in Getreide und Futtermitteln. Mycotoxin Res. 18, 35-38

Ribelin W.E., 1978. Trichothecene toxicosis in cattle. In: T.D. Wyllie, L.G. Morehouse (Editors). Mycotoxic Fungi, Mycotoxins, Mycotoxicoses. An Encyclopedic Handbook. Vol. 3, pp. 36-45

Riley R.T., 1998. Mechanistic interactions of mycotoxins: Theoretical considerations. In: K.K. Sinha, D. Bhatnagar (Editors). Mycotoxins in Agriculture and Food Safety. Marcel Dekker Inc., New York, pp. 227-253

Roine K., Korpinen E.L., Kallela K., 1971. Mycotoxicosis as a probable cause of infertility in dairy cows. A case report. Nord. Vet. Med. 23, 628-633

Rotter B.A., Prelusky D.B., 1996. Toxicology of deoxynivalenol. Toxicol. Environ. Health 48, $1-34$

Sabater Vilar M., 2003. Assessment and intervention of food- and feed-borne mycotoxicoses. $\mathrm{PhD}$ Thesis, Department of Veterinary Pharmacology, Pharmacy and Toxicology, Utrecht University (The Netherlands)

Schuh M., 1981. Klinische Auswirkungen der in Österreich vorkommenden Mykotoxine. Wien. Tierärztl. Monatschr. 68, 308-312

Schuh M., 1983. The importance of fusariotoxicosis in Austrian domestic animals. Proceedings of $5^{\text {th }}$ International Conference on Production Diseases in Farm Animals, Uppsala, pp. 390-394

Schuh M., 1996. Schimmelpilzgifte - Probleme beim Rind. Der fortschrittliche Landwirt 21/96, SB7-SB8

Schuh M., Baumgartner W., 1988. Mikrobiologisch und mykotoxikologisch kontaminierte Futtermittel als Krankheitsursache bei Rindern. Wien. Tierärztl. Monatschr. 75, 329-333 
Scudamore K.A., Livesey C.T., 1998. Occurrence and significance of mycotoxins in forage crops and silage: a review. J. Sci. Food Agr. 77, 1-17

Seeling K., Lebzien P., Dänicke S., Spilke J., Südekum K.H., Flachowsky G., 2005. Effects of level of feed intake and Fusarium toxin contaminated wheat on rumen fermentation as well as on blood and milk parameters in cows. J. Anim. Physiol. Anim. Nutr. (submitted)

Shreeve B.J., Patterson D.S.P., Roberts B.A., 1979. The "carry-over" of aflatoxin, ochratoxin and zearalenone from naturally contaminated feed to tissues, urine and milk of dairy cows. Food Cosmet. Toxicol. 17, 151-152

Smith J.E., DiMenna M.E., McGowan L.T., 1986. Effect of Fusarium culture and zearalenone on the reproductive performance of ewes. Proc. N. Z. Soc. Anim. Prod. 46, 255-258

Smith J.F., DiMenna M.E., McGowan L.T., 1990. Reproductive performance of Coopworth ewes following oral doses of zearalenone before and after mating. J. Reprod. Fertil. 89, 99-106

Sniffen C.J., Robinson P.H., 1987. Protein and fiber digestion, passage and utilization in lactating cows. Microbial growth and flow as influenced by dietary manipulations. J. Dairy Sci. 70, 425-441

Sreemannarayana O., Frohlich A.A., Vitti T.G., Marquardt R.R., Abramson D., 1988. Studies of the tolerance and disposition of ochratoxin A in young calves. J. Anim. Sci. 66, 1703-1711

Steinhöfel O., 2002. Futterqualitätsprogramm 1996-2002. Mykotoxikologischer Befund von Silomaiisproben in Freistaat Sachsen. Personal communication

Steyn P.S., 1998. The biosynthesis of mycotoxins. Rev. Med.-Vet. Toulouse 149, 469-478

Swanson S.P., Nicoletti J., Rood H.D., Buck W.B., Cote L.M., Yoshizawa T., 1987. Metabolism of three trichothecene mycotoxins, T-2 toxin, diacetoxyscirpenol and deoxynivalenol, by bovine rumen microorganisms. J. Chromatogr. 414, 335-342

Tamminga S., Van Der Koelen C.J., Van Vuuren A.M., 1979. Effect of level of feed intake on nitrogen entering the small intestine of dairy cows. Livest. Prod. Sci. 6, 255-262

Tarr B., 1996. Effect of moldy feed and mycotoxins on cattle. ushttp://www.gov.on.ca/ omafra/ english/livestock/dairy/herd/food//us from $4^{\text {th }}$ January 2002

Tashiro F., Kawabata Y., Naoi M., Ueno I., 1980. Zearalenone-estrogen receptor interaction and RNA synthesis in rat uterus. Med. Mycol. 8, 311-320

Thalmann A., 1986. Fusarientoxine in Futtermitteln und Lebensmittelrohstoffen. Agrar- und Umweltforschung Baden-Württemberg 14, 1-14

Trenholm H.L., Thompson B.K., Hartin K.E., Greenhalgh R., McAllister A.J., 1985. Ingestion of vomitoxin (deoxynivalenol)-contaminated wheat by nonlactating dairy cows. J. Dairy Sci. 68, 1000-1005

Uden P., 1984. The effect of intake and hay concentrate ratio upon digestibility and digesta passage. Anim. Feed Sci. Tech. 11, 167-179

Ueno I., 1985. The toxicology of mycotoxins. Crit. Rev. Toxicol. 14, 99-132

Ueno Y., Tashiro F., 1981. $\alpha$-Zearalenol, a major hepatic metabolite in rats of zearalenone, an estrogenic mycotoxin of Fusarium species. J. Biochem. 89, 563-571

Urry W.H., Wehrmeister H.L., Hodge E.B., Hidy P.H., 1966. The structure of zearalenone. Tetrahedron Lett. 27, 3109-3114

Usleber E., Renz V., Märtlbauer E., Terplan G., 1992. Studies on the application of enzyme immunoassays for the fusarium mycotoxins deoxynivalenol, 3-acetyldeoxynivalenol, and zearalenone. J. Vet. Med. 39, 617-627

Usleber E., Schneider E., Märtlbauer E., 1998. Untersuchungen zum Vorkommen von Deoxynivalenol, Zearalenon und Fumonisinen in Speisegetreide. Mycotoxin Res. 14, 131-135

Valenta H., Dänicke S., Blüthgen A., 2002. Mycotoxins in soybean feedstuffs used in Germany. Mycotoxin Res. 18, 208-211 
Valenta H., Oldenburg E., 1995. Bestimmung von Zearalenon, $\alpha$-Zearalenol und $\beta$-Zearalenol in Maissilage mit HPLC und GC/MS. VDLUFA-Schriftreihe 40, 957-960

Valenta H., Vemmer H., 1996. In vitro-Untersuchungen zum Metabolismus von Zearalenon bei Inkubation mit Pansensaft. Mycotoxin Res. 12, 185-191

Vanyi A., Szemeredi G., Quarini L., Romvaryne S.E., 1974. Fusariotoxicosis egy szarvasmarhaallomanyban. Magy. Allatorv. Lapja 29, 544-546

Weaver G.A., Kurtz H.T., Behrens J.C., Robison T.S., Seguin B.E., Bates F.Y., Mirocha J.C., 1986a. Effect of zearalenone on the fertility of virgin dairy heifers. Amer. J. Vet. Res. 47, 1395-1397

Weaver G.A., Kurtz H.T., Behrens J.C., Robison T.S., Seguin B.E., Bates F.Y., Mirocha J.C., 1986b. Effect of zearalenone on dairy cows. Amer. J. Vet. Res. 47, 659-662

Westlake K., Mackie R.I., Dutton M.F., 1987a. Effects of several mycotoxins on the specific growth rate of Butyrivibrio fibrisolvens and toxin degradation. Appl. Environ. Microbiol. 53, 613-614

Westlake K., Mackie R.I., Dutton M.F., 1987b. T-2 toxin metabolism by ruminal bacteria and its effect on their growth. Appl. Environ. Microbiol. 53, 587-592

Westlake K., Mackie R.I., Dutton M.F., 1989. In vitro metabolism of mycotoxins in bacterial, protozoal and ovine ruminal fluid preparations. Anim. Feed Sci. Tech. 25, 169-178

Whitlow L.W., Hagler W.M., 1999. An association of mycotoxins with production, health and reproduction in dairy cattle and guidelines for prevention and treatment. In: T.P. Lyons, K.A. Jaques (Editors). Proceedings of Alltechs $15^{\text {th }}$ Annual Symposium. Nottingham University Press, Nottingham (UK), pp. 401-419

Whitlow L.W., Nebel R.L., Behlow R.F., Hagler W.M., Brownie C.F.G., 1986. Mycotoxins in North Carolina dairy feeds - a survey of 100 dairy farms. J. Dairy Sci. 69, Suppl. 1, 223 (Abstr.)

Windels H.F., DiCostanzo A., Goodrich R.D., 1995. Effect of deoxynivalenol from barley on performance and health of large frame crossbred steers. Minnesota Cattle Feed Report B-417. St. Paul, MN

Xiao H., Marquardt R.R., Frohlich A.A., Phillips T.D., Vitti T.G., 1991. Effect of a hay and a grain diet on the rate of hydrolysis of ochratoxin A in the rumen of sheep. J. Anim. Sci. 69, 37063714

\section{STRESZCZENIE}

\section{Znacznie toksyn Fusarium, deoxynivalenolu i zearalenonu, w żywieniu przeżuwaczy}

Deoxydivalenol (DON) i zearalenon (ZON), wytwarzane przez gatunki Fusarium, są mykotoksynami odgrywającymi znaczącą rolę w rolnictwie ze względu na ich wpływ na zdrowie zwierząt. ZON powoduje u zwierząt syndrom estrogeniczny, a umiarkowane dawki DON powodują zmniejszenie wydajności i odporności u zwierząt. Spośród zwierząt gospodarskich przeżuwacze lepiej tolerują oddziaływanie DON i ZON, a w konsekwencji producenci pasz dla przeżuwaczy mogą używać w produkcji mieszanek zboża i pasze objętościowe porażone toksynami Fusarium. W związku z intensywnym występowaniem toksyn w tzw. latach Fusarium możliwość ich wpływu na przeżuwacze nie może być pominięta. W literaturze można spotkać tylko nieliczne i sprzeczne dane dotyczące wpływu DON i ZON na przeżuwacze. W niniejszym opracowaniu przeglądowym omówiono kinetykę, biotransformację, efekt przenośny oraz oddziaływanie DON i ZON u przeżuwaczy. Rozważono i przedyskutowano również wielkość dawek i czas oddziaływania toksyn, jak też czynniki genetyczne i fizjologiczne i ich wpływ na zmienność reagowania przeżuwaczy na toksyczne działanie tych mykotoksyn. W podsumowaniu stwierdzono, że konieczne są dalsze badania nad wpływem DON i ZON na organizm przeżuwacza, szczególnie krów dojnych. 